\title{
傾斜した角溝内を転がる楕円体の反復的衝突運動
}

鈴木 栄司*1

\section{Repetitious colliding motion of the ellipsoidal body rolling on a slanted rectangular gutter}

Eiji SUZUKI*1

\author{
${ }^{* 1}$ Toy Research \\ 3-12-8 Yagawa, Kunitachi-shi, Tokyo 186-0015, Japan
}

Received: 22 September 2019; Revised: 12 December 2019; Accepted: 11 May 2020

\begin{abstract}
There are the conveying machines utilizing vibration which can transport the various parts of engineering products in succession. When the body to be carried has the axisymmetric shape like an ellipsoid, it does not need to vibrate the conveying machine, and the ellipsoidal body itself can roll down the stationary tilted track automatically. But it will continue to accelerate in speed and we cannot avoid the bump due to the over-speed at the goal. The author designed to prevent the over-speed rolling motion of this ellipsoidal body by setting the vertical walls on the both sides of the slope through the slight collision there. This way leads to simplify the complicated vibrating mechanism and further to decrease the consumption of power and the emission of noise \& vibration. The most important subject for realizing this simple conveying system is whether rolling and colliding motions of the body are sustained spontaneously or not. The purpose of this research is to clarify the behavior of the self-excited motion which this ellipsoidal body continues to roll down the tilted slope through the repetitious collision with the walls. The author analyzed this motion of the body as three dimensional descending movement of the rigid body without a fixed point. From this analysis, he could confirm the continuous rolling and colliding motions which were also observed in the experiments.
\end{abstract}

Keywords : Conveying machine, Repetitious slight collision, Ellipsoidal body, Slanted slope with side walls, Continuous rolling down motion

\section{1. 緒言}

機械部品等を連続的に搬送するのに，搬送面を振動させて移送する振動輸送方式がある（栗田他，2008）。しか し被搬送体が軸対称の楕円体に近い形状をしている場合，搬送軌道面を振動させなくても，搬送面に傾斜を付け るだけで，棈円体は自発的に転動しながら坂を下っていくが，そのままでは加速され続け，時刻とともに速度が 増大するばかりであり，搬送先地点での衝撃が避けられない，対策として斜面の両側に垂直な側壁を設けて，楕 円体がそこで小さな衝突を繰り返す構成にすると転動速度の暴走を防ぐことが出来る．また搬送装置の簡素化， 無動力化，騒音・振動の最小化も期待できる.

ここで重要なことは, 楕円体がこの「転がり衝突運動」を自動的に継続して発生し続けられるかどうかである. このような棈円体に近い形状物体の「転がり衝突運動」について，その挙動を調べた研究の例を著者はまだ知ら ない. 関連した研究としては，三次元のビリヤード力学（藤井他，2016）があるが，扱ったモデルが球体である こと，衝突も一回限りの現象を論じたものであり，本研究の対象モデルである楕円体の継続性のある反復的衝突

No.19-00345 [DOI:10.1299/transjsme.19-00345], J-STAGE Advance Publication date : 19 May, 2020

*1 正員, Toy リサーチ（†186-0015 東京都国立市矢川3-12-8）

E-mail of corresponding author: esuzuki2016@outlook.jp 
運動とは力学的にも明らかに異なっている．また反復性のある衝突振動の例として，ロッキング振動の研究（安 田他，2016，鄭，鈴木，2000）もあるが，加振される床と衝突運動する摇動物体は角状剛体であり，本研究の対 象モデルである転動している軸対称モデルとは異なっている.

本研究の目的は，このような傾斜した角溝内で，上述の回転棈円体が重力によるポテンシャルエネルギーを利 用して，自動的に転動衝突運動を反復的に繰り返しながら坂を下るメカニズムを明らかにすることである. 著者 は, この楕円体の運動を固定点を持たない剛体の三次元の運動として扱い解析した結果, 実験でも観察された反 復性のある転動衝突運動が，解析でも生じることが確認できた。

ここで楕円体の運動方程式（並進系＝第 4 章，回転系＝第 5 章）の導出過程で必要となる基礎的関係式を，女 らかじめ第 2 章と第 3 章で求めておくことにする.

\section{2. 角溝の坂面上の楕円体の姿勢を表す座標系}

\section{$2 \cdot 1$ 坂面上の固定座標系 O- $X Y Z$ から見た重心の座標表示}

図 1 に示寸ように, 水平に対して角度 $\beta$ [rad]だけ傾斜している角溝斜面と転動体である回転楕円体が滑ること なく接触しながら転がっているとする. 空間に固定した座標系として, 大文字の O-XYZを用いるとして， $X$ 軸を 坂面長手方向に沿ってとり, $Y$ 軸を水平に, $Z$ 軸は坂面である $X Y$ 平面に垂直にとることにする. また $X$ 軸, $Y$ 軸, $Z$ 軸に対応した単位ベクトルをそれぞれ $\boldsymbol{e}_{X}, \boldsymbol{e}_{Y}, \boldsymbol{e}_{Z}$ とする. 固定座標系 $\mathrm{O}-X Y Z$ から見た楕円体の重心 $\mathrm{G}$ の座標 を $\left(X_{G}, Y_{G}, Z_{G}\right)[\mathrm{m}]$ とすれば, 位置ベクトル $\overrightarrow{\mathrm{OG}}=\boldsymbol{R}_{G}$ は次式で示される.

$$
\boldsymbol{R}_{G}=X_{G} \boldsymbol{e}_{X}+Y_{G} \boldsymbol{e}_{Y}+Z_{G} \boldsymbol{e}_{Z}
$$

また溝の幅を $u[\mathrm{~m}]$ とする. さらに楕円体の重心 $\mathrm{G}$ を通り， $X, Y, Z$ 軸に平行な座標軸を $/ / X, I / Y, I / Z$ として, 各 軸に対応した単位ベクトルを $\boldsymbol{e}_{/ X}, \boldsymbol{e}_{/ / Y}, \boldsymbol{e}_{/ / Z}$ とする. この時, 次式が成立している.

$$
\boldsymbol{e}_{/ / X}=\boldsymbol{e}_{X}, \boldsymbol{e}_{/ / Y}=\boldsymbol{e}_{Y}, \boldsymbol{e}_{/ / Z}=\boldsymbol{e}_{\mathrm{Z}}
$$

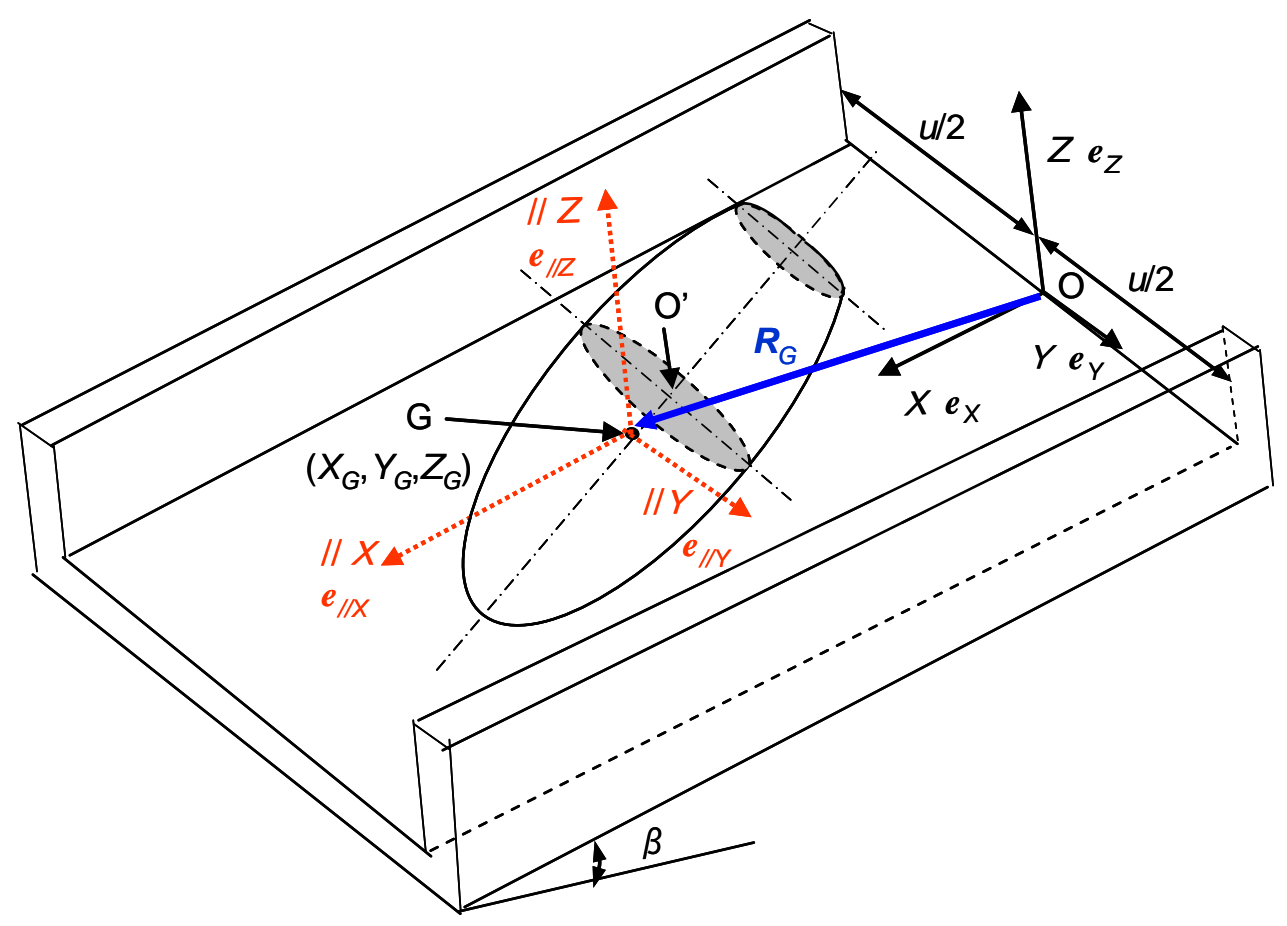

Fig.1 Coordinate axes $\mathrm{O}-\mathrm{XYZ}$ which are fixed on the slanted rectangular gutter and the position of the mass center of the ellipsoidal body shown by these axes. $\boldsymbol{e}_{X}, \boldsymbol{e}_{Y}, \boldsymbol{e}_{Z}$ and $\boldsymbol{e}_{/ / X}, \boldsymbol{e}_{/ / Y}, \boldsymbol{e}_{/ / Z}$ are the corresponding unit vectors. 


\section{$2 \cdot 2$ 転動棈円体の諸元と重心を通る歳差運動座標系 G- $x$ y z}

軸対称の転動体として，より一般性のある形状である長軸側の一端が切り取られた楕円体を考え，その形状を 図 2 に示した. 楕円体の形状中心を $\mathrm{O}^{\prime}$ として重心 $\mathrm{G}$ とのずれ量 $\mathrm{GO}^{\prime}=\varepsilon[\mathrm{m}]$ とする. 楕円体を基準にした重心 $\mathrm{G}$ を通る歳差運動座標系 $\mathrm{G}-x y z$ を考える. 即ち楕円体の長軸を $x$ 軸にとり，角溝斜面である $X Y$ 面に平行に $y$ 軸を とる. $z$ 軸は $x y$ 平面に垂直な方向にとるものとする. $x y z$ 各軸に対応した単位ベクトルを $\boldsymbol{e}_{x}, \boldsymbol{e}_{y}, \boldsymbol{e}_{z}$ とする.

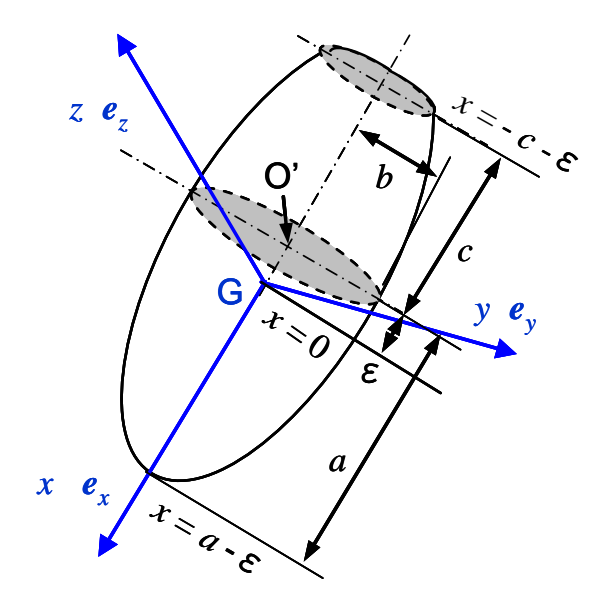

Fig.2 Dimensions of the rolling ellipsoidal body. The $x, y, z$ axes are precession coordinates.

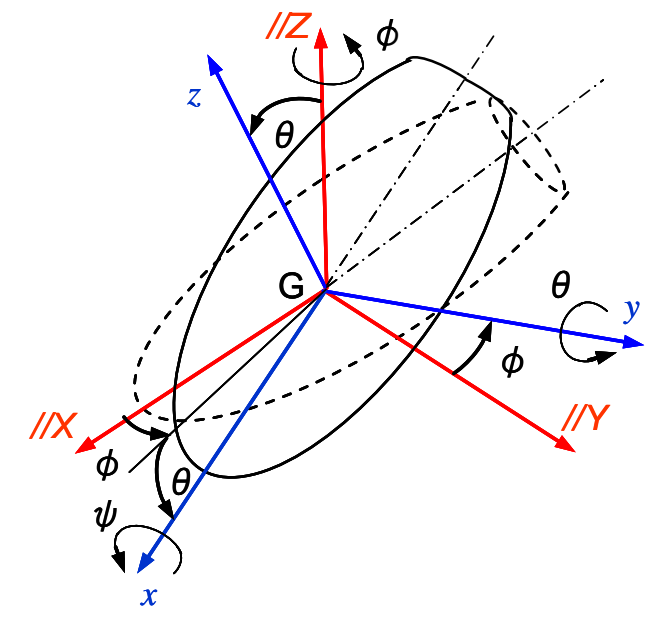

Fig.3 Eulerian angles $\phi, \theta$ and $\psi$ around the center of gravity of the ellipsoidal body. Spinning angle $\psi$ is adopted as the angle around $x$ axis in this model.

楕円体の長半径を $a[\mathrm{~m}]$, 短半径を $b[\mathrm{~m}],-x$ 軸方向後端部の切り取り長さを $(a-c)[\mathrm{m}]$ とすれば, 歳差運動座 標系で表した楕円体の方程式は

$$
\frac{(x+\varepsilon)^{2}}{a^{2}}+\frac{y^{2}}{b^{2}}+\frac{z^{2}}{b^{2}}=1
$$

と示される．さらに楕円体の密度を $\rho\left[\mathrm{kg} / \mathrm{m}^{3}\right]$, 質量を $m[\mathrm{~kg}], x, y, z$ 各軸回りの主慣性モーメントを $A\left[\mathrm{kgm}^{2}\right]$, $B\left[\mathrm{kgm}^{2}\right], C\left[\mathrm{kgm}^{2}\right]$ とすれば，次式のように表される.

$$
\left.\begin{array}{rl}
\varepsilon & =\frac{3\left(a^{2}-c^{2}\right)^{2}}{4\left(2 a^{3}+3 a^{2} c-c^{3}\right)}, \quad m=\frac{\pi \rho b^{2}}{3 a^{2}}\left(2 a^{3}+3 a^{2} c-c^{3}\right) \quad, \quad A=\frac{\pi \rho b^{4}}{30 a^{4}}\left(8 a^{5}+15 a^{4} c-10 a^{2} c^{3}+3 c^{5}\right) \\
B & =C \\
& =\frac{\pi \rho b^{2}(a+c)}{20 a^{4}}\left[(a-c-2 \varepsilon)\left\{(a-\varepsilon)^{2}+(c+\varepsilon)^{2}\right\}\left\{b^{2}(a+4 \varepsilon)-2 a^{2}(2 a+3 \varepsilon)\right\}+\left(b^{2}-4 a^{2}\right)(c+\varepsilon)^{4}\right. \\
& \left.+10 b^{2} \varepsilon\left(\varepsilon^{2}-a^{2}\right)(a-c-2 \varepsilon)+5 b^{2}\left(a^{2}-\varepsilon^{2}\right)^{2}+(10 / 3)\left\{2 a^{2}\left(a^{2}-\varepsilon^{2}\right)-b^{2}\left(a^{2}-3 \varepsilon^{2}\right)\right\}\left\{(a-3 \varepsilon)(a-c)+3 \varepsilon^{2}+c^{2}\right\}\right]
\end{array}\right\}
$$

\section{$2 \cdot 3$ オイラー角 $\phi ， \theta ， \psi$ を用いた楕円体表面上の点 $S$ の位置ベクトルとそこでの接平面の式}

転動体である楕円体は, その運動に伴い図 3 に示寸ようにオイラー角 $\phi, \theta, \psi$ だけ回転変化することになる.

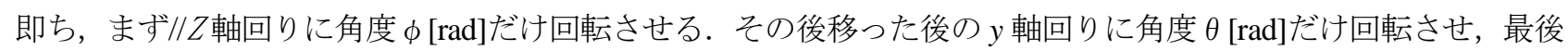
に移った後の $x$ 軸回りにスピン角度 $\psi[\mathrm{rad}]$ だけ自回転させた状態を考える. ただし歳差運動座標系 $\mathrm{G}-x$ y $z$ 自体 は $\psi$ と共には回転しない，スピン角度 $\psi$ は通常は $z$ 軸回りにとるのが一般的だが，本モデルでは $x$ 軸回りに採っ てある，楕円体は転動しながら角溝斜面と接するとともに，溝側面とも衝突して接する形になる．これら両方の 運動形態を扱う必要があるので，一般化した楕円体表面上の点 $\mathrm{S}$ を導入して解析を進めることにする. 
式(2)を考慮すると，単位ベクトル $\boldsymbol{e}_{X}, \boldsymbol{e}_{Y}, \boldsymbol{e}_{Z}$ と $\boldsymbol{e}_{x}, \boldsymbol{e}_{y}, \boldsymbol{e}_{z}$ の間には次の関係が成立している.

$$
\left(\begin{array}{l}
\boldsymbol{e}_{X} \\
\boldsymbol{e}_{Y} \\
\boldsymbol{e}_{Z}
\end{array}\right)=\left(\begin{array}{ccc}
\cos \phi \cos \theta & -\sin \phi & \cos \phi \sin \theta \\
\sin \phi \cos \theta & \cos \phi & \sin \phi \sin \theta \\
-\sin \theta & 0 & \cos \theta
\end{array}\right)\left(\begin{array}{l}
\boldsymbol{e}_{x} \\
\boldsymbol{e}_{y} \\
\boldsymbol{e}_{z}
\end{array}\right)
$$

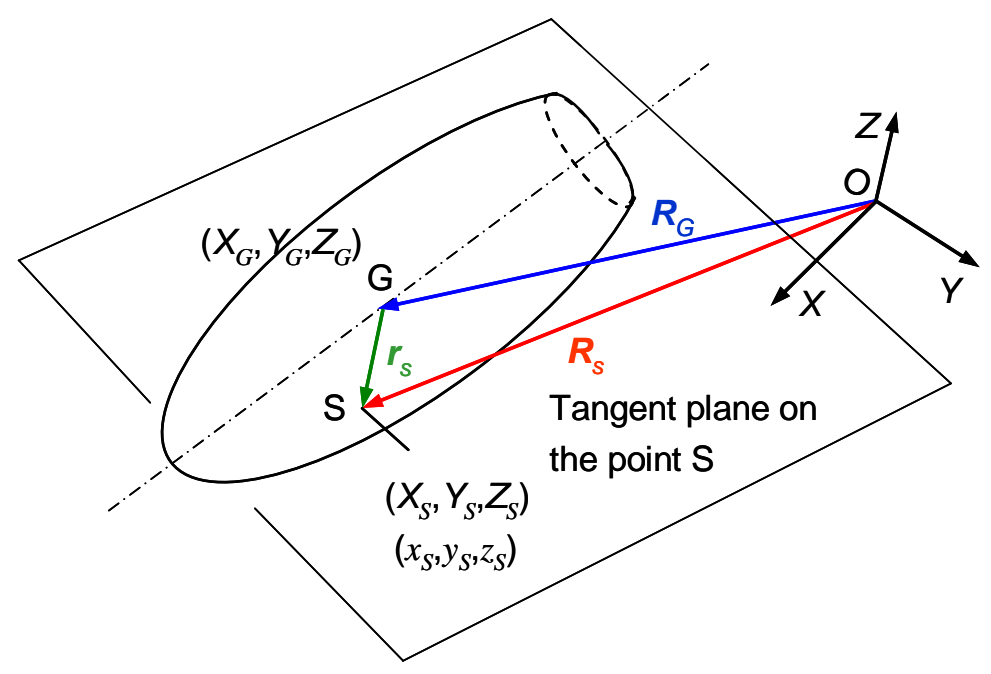

Fig.4 Tangent plane on the point $\mathrm{S}$ in contact with the ellipsoidal body.

今, 図 4 に示すように, 楕円体の表面の任意の点 $\mathrm{S}$ において接している接平面を考える. 固定座標系 $\mathrm{O}-X Y Z$ か ら見た点 $\mathrm{S}$ の座標を $\left(X_{S}, Y_{S}, Z_{S}\right)[\mathrm{m}]$ とし, 位置ベクトルとして $\overrightarrow{\mathrm{OS}}=\boldsymbol{R}_{S}$ とすれば

$$
\boldsymbol{R}_{S}=X_{S} \boldsymbol{e}_{X}+Y_{S} \boldsymbol{e}_{Y}+Z_{S} \boldsymbol{e}_{Z}
$$

と表される. さらに歳差運動座標系 $\mathrm{G}-x y z$ から見た点 $\mathrm{S}$ の座標を $\left(x_{S}, y_{S}, z_{S}\right)$ [m]とすれば, 点 $\mathrm{S}$ の位置ベクト ル $\overrightarrow{\mathrm{GS}}=\boldsymbol{r}_{S}$ は，式(5)の関係を用いると次式のように表される.

$$
\begin{aligned}
\boldsymbol{r}_{S} & =x_{S} \boldsymbol{e}_{x}+y_{S} \boldsymbol{e}_{y}+z_{S} \boldsymbol{e}_{z} \\
& =\left(x_{S} \cos \theta \cos \phi-y_{S} \sin \phi+z_{S} \sin \theta \cos \phi\right) \boldsymbol{e}_{X} \\
& +\left(x_{S} \cos \theta \sin \phi+y_{S} \cos \phi+z_{S} \sin \theta \sin \phi\right) \boldsymbol{e}_{Y}+\left(-x_{S} \sin \theta+z_{S} \cos \theta\right) \boldsymbol{e}_{Z}
\end{aligned}
$$

一方

$$
\begin{aligned}
\boldsymbol{r}_{S} & =\boldsymbol{R}_{S}-\boldsymbol{R}_{G} \\
& =\left(X_{S}-X_{G}\right) \boldsymbol{e}_{X}+\left(Y_{S}-Y_{G}\right) \boldsymbol{e}_{Y}+\left(Z_{S}-Z_{G}\right) \boldsymbol{e}_{Z}
\end{aligned}
$$

が成立しているので，式(7)(8)の右辺同士を等しく置くと

$$
\left(\begin{array}{c}
X_{S}-X_{G} \\
Y_{S}-Y_{G} \\
Z_{S}-Z_{G}
\end{array}\right)=\left(\begin{array}{ccc}
\cos \phi \cos \theta & -\sin \phi & \cos \phi \sin \theta \\
\sin \phi \cos \theta & \cos \phi & \sin \phi \sin \theta \\
-\sin \theta & 0 & \cos \theta
\end{array}\right)\left(\begin{array}{c}
x_{S} \\
y_{S} \\
z_{S}
\end{array}\right)
$$

の関係式が得られる.ささに楕円体表面上の点 $\mathrm{S}$ に接する接平面の式は次式で与えられる.

$$
\begin{aligned}
& \left(X-X_{S}\right)\left\{\left(x_{S}+\varepsilon\right) \cos \theta \cos \phi-(a / b)^{2} y_{S} \sin \phi+(a / b)^{2} z_{S} \sin \theta \cos \phi\right\} \\
& +\left(Y-Y_{S}\right)\left\{\left(x_{S}+\varepsilon\right) \cos \theta \sin \phi+(a / b)^{2} y_{S} \cos \phi+(a / b)^{2} z_{S} \sin \theta \sin \phi\right\} \\
& +\left(Z-Z_{S}\right)\left\{-\left(x_{S}+\varepsilon\right) \sin \theta+(a / b)^{2} z_{S} \cos \theta\right\}=0
\end{aligned}
$$




\section{3. 角速度ベクトルと接点 Sでの滑り速度}

\section{$3 \cdot 1$ 角速度ベクトル $\Omega$ と $\omega$}

時刻を $t$ [s] とした時，棈円体の重心 $\mathrm{G}$ 回りの歳差運動座標系 $\mathrm{G}-x y z$ の回転角速度ベクトル $\boldsymbol{\Omega}$ は

$$
\boldsymbol{\Omega}=\frac{\mathrm{d} \phi}{\mathrm{d} t} \boldsymbol{e}_{Z}+\frac{\mathrm{d} \theta}{\mathrm{d} t} \boldsymbol{e}_{y}
$$

と表わされる，一方，式(5)より

$$
\boldsymbol{e}_{Z}=-\sin \theta \boldsymbol{e}_{x}+\cos \theta \boldsymbol{e}_{z}
$$

の関係があるので，式(12)を式(11)に代入すると

$$
\boldsymbol{\Omega}=-\frac{\mathrm{d} \phi}{\mathrm{d} t} \sin \theta \boldsymbol{e}_{x}+\frac{\mathrm{d} \theta}{\mathrm{d} t} \boldsymbol{e}_{y}+\frac{\mathrm{d} \phi}{\mathrm{d} t} \cos \theta \boldsymbol{e}_{z}
$$

となる.さらに

$$
\begin{aligned}
& \frac{\mathrm{d} \boldsymbol{e}_{x}}{\mathrm{~d} t}=\boldsymbol{\Omega} \times \boldsymbol{e}_{x}=\frac{\mathrm{d} \phi}{\mathrm{d} t} \cos \theta \boldsymbol{e}_{y}-\frac{\mathrm{d} \theta}{\mathrm{d} t} \boldsymbol{e}_{z} \\
& \frac{\mathrm{d} \boldsymbol{e}_{y}}{\mathrm{~d} t}=\Omega \times \boldsymbol{e}_{y}=-\frac{\mathrm{d} \phi}{\mathrm{d} t} \cos \theta \boldsymbol{e}_{x}-\frac{\mathrm{d} \phi}{\mathrm{d} t} \sin \theta \boldsymbol{e}_{z} \\
& \frac{\mathrm{d} \boldsymbol{e}_{z}}{\mathrm{~d} t}=\Omega \times \boldsymbol{e}_{z}=\frac{\mathrm{d} \theta}{\mathrm{d} t} \boldsymbol{e}_{x}+\frac{\mathrm{d} \phi}{\mathrm{d} t} \sin \theta \boldsymbol{e}_{y}
\end{aligned}
$$

が成立している. 式(14)の関係式は後ほどの楕円体の回転系運動方程式を導く際に用いることになる. 楕円体の $x$ 軸回りのスピン角速度 $\mathrm{d} \psi / \mathrm{d} t$ を考慮した角速度ベクトルを $\omega$ とすれば

$$
\begin{aligned}
\omega & =\Omega+\dot{\psi} \boldsymbol{e}_{x} \\
& =(-\dot{\phi} \sin \theta+\dot{\psi}) \boldsymbol{e}_{x}+\dot{\theta} \boldsymbol{e}_{y}+\dot{\phi} \cos \theta \boldsymbol{e}_{z}
\end{aligned}
$$

と表される。ここに $(\cdot)$ は，時刻 $t$ に関する微分を意味している.

\section{$3 \cdot 2$ 接点Sでの滑り速度 $v_{S}$}

図 4 からもわかるように, 接点 $\mathrm{S}$ の位置ベクトル $\boldsymbol{R}_{S}$ と $\boldsymbol{r}_{S}$ 及び重心の位置ベクトル $\boldsymbol{R}_{G}$ の間には式(8)が成立して いる.すなわち

$$
\boldsymbol{R}_{S}=\boldsymbol{R}_{G}+\boldsymbol{r}_{S}
$$

接点 $\mathrm{S}$ における楕円体の速度べクトルを $\boldsymbol{v}_{S}$ とすると， $\boldsymbol{v}_{S}$ は式(16)を時刻 $t$ で微分して

$$
\begin{aligned}
v_{S} & =\dot{\boldsymbol{R}}_{S}=\dot{\boldsymbol{R}}_{G}+\dot{\boldsymbol{r}}_{S} \\
& =\dot{\boldsymbol{R}}_{G}+\left(\delta \boldsymbol{r}_{S} / \delta t\right)+\omega \times \boldsymbol{r}_{S}
\end{aligned}
$$

となる.ここに $\delta \boldsymbol{r}_{S} / \delta t$ は歳差運動座標系で表した $\boldsymbol{r}_{S}$ の成分のみを時刻 $t$ で微分したものを意味する．即ち式(7) より

$$
\frac{\delta \boldsymbol{r}_{S}}{\delta t}=\dot{x}_{S} \boldsymbol{e}_{x}+\dot{y}_{S} \boldsymbol{e}_{y}+\dot{z}_{S} \boldsymbol{e}_{z}
$$

また式(17)の $\omega \times \boldsymbol{r}_{S}$ については，式(15)の $\omega$ と式(7)の $\boldsymbol{r}_{S}$ を用いると次式のようになる. 


$$
\begin{aligned}
\omega \times \boldsymbol{r}_{S} & =\left\{(-\dot{\phi} \sin \theta+\dot{\psi}) \boldsymbol{e}_{x}+\dot{\theta} \boldsymbol{e}_{y}+\dot{\phi} \cos \theta \boldsymbol{e}_{z}\right\} \times\left(x_{S} \boldsymbol{e}_{x}+y_{S} \boldsymbol{e}_{y}+z_{S} \boldsymbol{e}_{z}\right) \\
& =\left(\dot{\theta} z_{S}-\dot{\phi} \cos \theta y_{S}\right) \boldsymbol{e}_{x}+\left\{(\dot{\phi} \sin \theta-\dot{\psi}) z_{S}+\dot{\phi} \cos \theta x_{S}\right\} \boldsymbol{e}_{y}+\left\{(-\dot{\phi} \sin \theta+\dot{\psi}) y_{S}-\dot{\theta} x_{S}\right\} \boldsymbol{e}_{z}
\end{aligned}
$$

式(18)(19)において, 式(5)の関係を用いて $\boldsymbol{e}_{X}, \boldsymbol{e}_{Y}, \boldsymbol{e}_{Z}$ を用いた表現にした後, 式(17)に代入すると最終的に $\boldsymbol{v}_{S}$ は 次のように表される.

$$
\begin{aligned}
v_{S}= & \left\{\dot{X}_{G}+\dot{x}_{S} \cos \theta \cos \phi-\dot{y}_{S} \sin \phi+\dot{z}_{S} \sin \theta \cos \phi-(\dot{\phi} \sin \phi \cos \theta+\dot{\theta} \sin \theta \cos \phi) x_{S}+(-\dot{\phi}+\dot{\psi} \sin \theta) \cos \phi y_{S}\right. \\
& \left.+(\dot{\theta} \cos \theta \cos \phi-\dot{\phi} \sin \theta \sin \phi+\dot{\psi} \sin \phi) z_{S}\right\} \boldsymbol{e}_{X} \\
& +\left\{\dot{Y}_{G}+\dot{x}_{S} \cos \theta \sin \phi+\dot{y}_{S} \cos \phi+\dot{z}_{S} \sin \theta \sin \phi+(\dot{\phi} \cos \phi \cos \theta-\dot{\theta} \sin \theta \sin \phi) x_{S}+(-\dot{\phi}+\dot{\psi} \sin \theta) \sin \phi y_{S}\right. \\
& \left.+(\dot{\theta} \cos \theta \sin \phi+\dot{\phi} \sin \theta \cos \phi-\dot{\psi} \cos \phi) z_{S}\right\} \boldsymbol{e}_{Y} \\
& +\left\{\dot{Z}_{G}-\dot{x}_{S} \sin \theta+\dot{z}_{S} \cos \theta-\dot{\theta} \cos \theta x_{S}+\dot{\psi} \cos \theta y_{S}-\dot{\theta} \sin \theta z_{S}\right\} \boldsymbol{e}_{Z}
\end{aligned}
$$

\section{4. 棈円体の並進系運動方程式の導出}

\section{$4 \cdot 1$ 接地点 $P$ の座標}

ここでは楕円体が斜面を転動するだけで，溝側面との衝突は生じていない状況を主体に考える。この場合は $2 \cdot 3$ 節で述べた接点 $\mathrm{S}$ は, 楕円体が溝斜面と接する接地点 $\mathrm{P}$ に相当し, 接平面は斜面に相当する (図 5 参照).

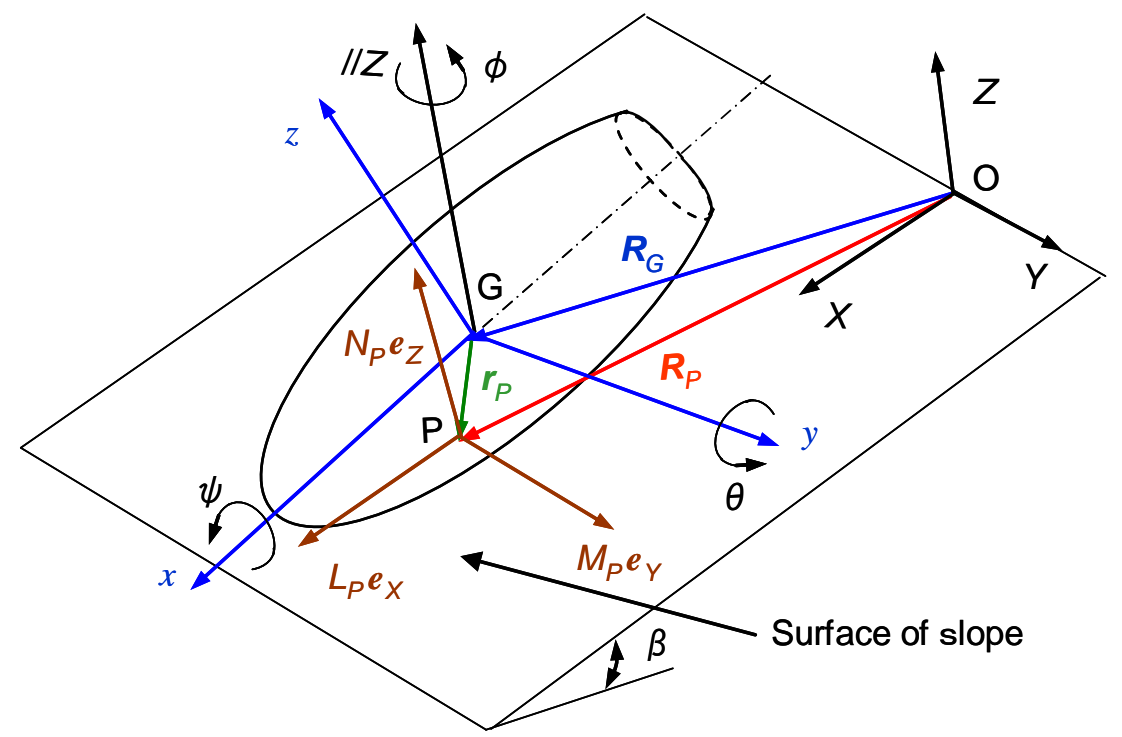

Fig.5 Resistant forces acting upon the ellipsoidal body at the point $\mathrm{P}$ in contact with the slope.

接地点 $\mathrm{P}$ は常に坂面上の点であるから

$$
y_{P}=0, Z_{P}=0
$$

が成立している，P点で接する接平面である溝斜面の式は, 式(10)において添字 ${ }_{S}$ の表記を $P$ に換え, $Z=0$ と式(21) を考慮すると

$$
\left\{\left(x_{P}+\varepsilon\right) \cos \theta+(a / b)^{2} z_{P} \sin \theta\right\}\left\{\left(X-X_{P}\right) \cos \phi+\left(Y-Y_{P}\right) \sin \phi\right\}=0
$$

となる．溝斜面上の任意の点 $(X, Y)$ で式(22)が成立するには

$$
\left(x_{P}+\varepsilon\right) \cos \theta+(a / b)^{2} z_{P} \sin \theta=0
$$


を満たしている必要がある。一方 $x_{P}, y_{P}(=0), z_{P}$ は式(3)を満足しているので, 式(23)と連立させて $x_{P}, z_{P}(<0)$ を求 めると, $u<2 a$ であり溝斜面の下流側に向いて楕円体が位置する限り, 自重により $x$ 軸方向には前下がりの傾き $(\theta$ $>0$ ）をとるので次式(24)が得られる.

$$
\left.\begin{array}{l}
x_{P}=\frac{\left(a^{2} / b\right) \sin \theta}{\sqrt{(a / b)^{2} \sin ^{2} \theta+\cos ^{2} \theta}}-\varepsilon \\
y_{P}=0 \\
z_{P}=\frac{-b \cos \theta}{\sqrt{(a / b)^{2} \sin ^{2} \theta+\cos ^{2} \theta}}
\end{array}\right\}
$$

同上理由から，接地点 $\mathrm{P} の x$ 座標 $x_{P}$ は正となり，楕円体の重心 $\mathrm{G}$ は接地点 $\mathrm{P}$ より常に斜面の上流側に位置する ので，楕円体は重力により横方向（ $\phi$ 及び $Y$ 方向）に転がろうとする.

\section{$4 \cdot 2$ 接地点Pにおける抗力}

転動する楕円体と溝斜面との接地点 $\mathrm{P}$ は点接触なのでモーメントは発生しない. 図 5 に示すように, P 点にお ける抗力を $\boldsymbol{F}_{P}$ として，その $X, Y, Z$ 方向成分をそれぞれ $L_{P}[\mathrm{~N}], M_{P}[\mathrm{~N}], N_{P}[\mathrm{~N}]$ とすれば

$$
\boldsymbol{F}_{P}=L_{P} \boldsymbol{e}_{X}+M_{P} \boldsymbol{e}_{Y}+N_{P} \boldsymbol{e}_{Z}
$$

と表現される.

\section{$4 \cdot 3$ 楕円体の並進系運動方程式の導出}

楕円体には, $\boldsymbol{F}_{P}$ 以外に重心 $\mathrm{G}$ に重力 $m \boldsymbol{g}$ が作用しているので, 重力加速度を $g\left(=9.8 \mathrm{~m} / \mathrm{s}^{2}\right)$ とすれば, 重心 $\left(X_{G}\right.$, $\left.Y_{G}, Z_{G}\right)$ に関する並進系運動方程式は次式のように表される.

$$
m \ddot{\boldsymbol{R}}_{G}=\boldsymbol{F}_{P}+m g \sin \beta \boldsymbol{e}_{X}-m g \cos \beta \boldsymbol{e}_{Z}
$$

式(1)の $\boldsymbol{R}_{G}$ 及び式(25)の $\boldsymbol{F}_{P}$ を式(26)に代入して, 両辺の $\boldsymbol{e}_{X}, \boldsymbol{e}_{Y}, \boldsymbol{e}_{Z}$ の係数を等しく置くと, 次式が得られる.

$$
\left.\begin{array}{rl}
m \ddot{X}_{G} & =L_{P}+m g \sin \beta \\
\ddot{Y}_{G} & =M_{P} \\
m \ddot{Z}_{G} & =N_{P}-m g \cos \beta
\end{array}\right\}
$$

\section{5. 楕円体の回転系運動方程式の算出}

\section{$5 \cdot 1$ 棈円体の重心回りに作用するモーメント}

楕円体の重心回りに作用するモーメントベクトルを $\boldsymbol{T}$ とすると, 重力の作用線は重心 Gを通りモーメント成分 は有さないので

$$
\boldsymbol{T}=\boldsymbol{r}_{P} \times \boldsymbol{F}_{P}
$$

と表現される. ここに $\boldsymbol{r}_{P}$ は歳差運動座標系から見た $\mathrm{P}$ 点の位置ベクトルであり, 式(7)中の添字 $s$ の表記の代わり に ${ }_{P}$ としたものである. この $\boldsymbol{r}_{P}$ と式(25)の $\boldsymbol{F}_{P}$ を式(28)に代入すると

$$
\begin{aligned}
\boldsymbol{T} & =\left\{M_{P}\left(x_{P} \sin \theta-z_{P} \cos \theta\right)+N_{P}\left(x_{P} \cos \theta \sin \phi+y_{P} \cos \phi+z_{P} \sin \theta \sin \phi\right)\right\} \boldsymbol{e}_{X} \\
& +\left\{L_{P}\left(-x_{P} \sin \theta+z_{P} \cos \theta\right)-N_{P}\left(x_{P} \cos \theta \cos \phi-y_{P} \sin \phi+z_{P} \sin \theta \cos \phi\right)\right\} \boldsymbol{e}_{Y} \\
& +\left\{-L_{P}\left(x_{P} \cos \theta \sin \phi+y_{P} \cos \phi+z_{P} \sin \theta \sin \phi\right)+M_{P}\left(x_{P} \cos \theta \cos \phi-y_{P} \sin \phi+z_{P} \sin \theta \cos \phi\right)\right\} \boldsymbol{e}_{Z}
\end{aligned}
$$


となる.さらに式(5)を用いて，歳差運動座標系から見た表現に書き換えると

$$
\boldsymbol{T}=T_{x} \boldsymbol{e}_{x}+T_{y} \boldsymbol{e}_{y}+T_{z} \boldsymbol{e}_{z}
$$

と表される.ここに $T_{x}[\mathrm{Nm}], T_{y}[\mathrm{Nm}], T_{z}[\mathrm{Nm}]$ は

$$
\left.\begin{array}{l}
T_{x}=L_{P}\left(y_{P} \sin \theta \cos \phi+z_{P} \sin \phi\right)+M_{P}\left(y_{P} \sin \theta \sin \phi-z_{P} \cos \phi\right)+N_{P} y_{P} \cos \theta \\
T_{y}=\left(L_{P} \cos \phi+M_{P} \sin \phi\right)\left(-x_{P} \sin \theta+z_{P} \cos \theta\right)-N_{P}\left(x_{P} \cos \theta+z_{P} \sin \theta\right) \\
T_{z}=L_{P}\left(-x_{P} \sin \phi+y_{P} \cos \theta \cos \phi\right)+M_{P}\left(x_{P} \cos \phi-y_{P} \cos \theta \sin \phi\right)+N_{P} y_{P} \sin \theta
\end{array}\right\}
$$

で示される.

\section{$5 \cdot 2$ 角運動量ベクトルと回転系運動方程式の導出}

楕円体の重心回りの角運動量ベクトルを $L$, 慣性テンソルを $I$ とする. 式(15)で示された角速度ベクトル $\omega$ を 用いて $L$ を表すと

$$
\begin{aligned}
\boldsymbol{L} & =\boldsymbol{I} \cdot \boldsymbol{\omega} \\
& =A(-\dot{\phi} \sin \theta+\dot{\psi}) \boldsymbol{e}_{x}+C \dot{\theta} \boldsymbol{e}_{y}+C \dot{\phi} \cos \theta \boldsymbol{e}_{z}
\end{aligned}
$$

となる.ただし式(4)で示された主慣性モーメントのうち, 楕円体が $x$ 軸回りに対称性を有しているので, $B=C$ を 考慮した.

楕円体の重心 $G$ 回りの回転系運動方程式は

$$
\frac{\mathrm{d} \boldsymbol{L}}{\mathrm{d} t}=\boldsymbol{T}=T_{x} \boldsymbol{e}_{x}+T_{y} \boldsymbol{e}_{y}+T_{z} \boldsymbol{e}_{z}
$$

と表される. 式(33)の左辺を計算するために, 式(32)を時刻 $t$ で微分した後, 式(14)の関係式を用いて整理すると

$$
\begin{aligned}
\frac{\mathrm{d} \boldsymbol{L}}{\mathrm{d} t}= & A(\ddot{\ddot{\psi}}-\ddot{\phi} \sin \theta-\dot{\phi} \dot{\theta} \cos \theta) \boldsymbol{e}_{x}+\left\{C \ddot{\theta}+A \dot{\psi} \dot{\phi} \cos \theta+(C-A) \dot{\phi}^{2} \sin \theta \cos \theta\right\} \boldsymbol{e}_{y} \\
& +\{C \ddot{\phi} \cos \theta+(A-2 C) \dot{\theta} \dot{\phi} \sin \theta-A \dot{\theta} \dot{\psi}\} \boldsymbol{e}_{z}
\end{aligned}
$$

となる. 式(34)を式(33)の左辺に代入すると, 最終的に楕円体の回転系運動方程式として, 次の三式が得られる. 各式の右辺の $T_{x}, T_{y}, T_{z}$ は式(31)で示されたものである.

$$
\begin{aligned}
& A(\ddot{\psi}-\ddot{\phi} \sin \theta-\dot{\phi} \dot{\theta} \cos \theta)=T_{x} \\
& C \ddot{\theta}+A \dot{\psi} \dot{\phi} \cos \theta+(C-A) \dot{\phi}^{2} \sin \theta \cos \theta=T_{y} \\
& \ddot{C} \cos \theta+(A-2 C) \dot{\theta} \dot{\phi} \sin \theta-A \dot{\theta} \dot{\psi}=T_{z}
\end{aligned}
$$

結局，転動する楕円体の並進系運動方程式は式(27)の三式で示され，重心回りの回転系運動方程式は式(35)(36) (37)の三式で示されたことになる.

\section{6. $\theta=$ 一定とした時の並進 \&回転連立運動方程式の解}

楕円体のピッチング角 $\theta$ については，実験での挙動観察から少し変動はしているものの，慣性力に伴う変動が 主体ではなく, 重力の静的バランス状態での $\phi$ の変化に伴うものだと推測された. 観察結果からその変動幅も小 さいので $\theta=$ 一定 $\left(=\theta_{0}\right.$ o) と見なして差し支えないと考えた. 


\section{6・1 $\theta=\theta_{0}$ （一定）とした時の運動方程式}

$\theta=\theta_{0}$ と一定の場合は，式(24)より

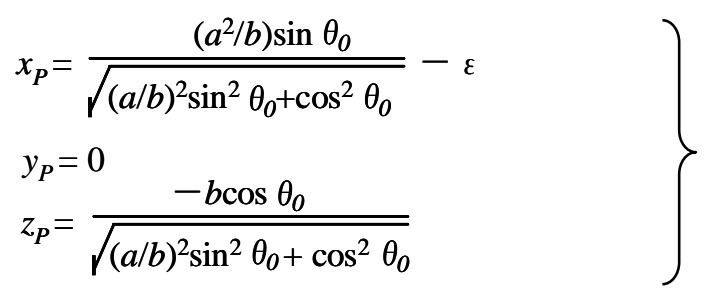

となり， $x_{P}, y_{P}(=0), z_{P}$ も一定の值をとることがわかる. 一方，楕円体重心の $Z$ 座標 $Z_{G}$ は，式(9)において ${ }_{S}$ 表記 を ${ }_{P}$ に換えるとともに， $Z_{P}=0$ であるので

$$
Z_{G}=x_{P} \sin \theta_{0}-z_{P} \cos \theta_{0}
$$

を得る。式(39)の $x_{P} ， z_{P}$ に式(38)を代入すると

$$
Z_{G}=\sqrt{a^{2} \sin ^{2} \theta_{0}+b^{2} \cos ^{2} \theta_{0}}-\varepsilon \sin \theta_{0}
$$

となり，楕円体の重心の $Z$ 座標も一定值をとる. すなわち $\mathrm{d} Z_{G} / \mathrm{d} t=0, \mathrm{~d}^{2} Z_{G} / \mathrm{d} t^{2}=0$ となるので，式(27)の第三式に 代入すると

$$
N_{P}=m g \cos \beta
$$

が得られる．結局 $\theta=\theta_{0}$ と一定の時は，重心の並進系運動方程式として式(27)の第三式が除かれ

$$
\begin{aligned}
m \ddot{X}_{G} & =L_{P}+m g \sin \beta \\
\ddot{Y}_{G} & =M_{P}
\end{aligned}
$$

となる．さらに回転系運動方程式である式(35)(37)において， $\theta=\theta_{0} ， y_{P}=0$ を考慮すると

$$
\begin{aligned}
& A\left(\ddot{\psi}-\ddot{\phi} \sin \theta_{0}\right)=z_{P}\left(L_{P} \sin \phi-M_{P} \cos \phi\right) \\
& C \ddot{\phi} \cos \theta_{0}=-x_{P}\left(L_{P} \sin \phi-M_{P} \cos \phi\right)
\end{aligned}
$$

と簡単化される。つまり運動方程式群は式(42)〜式(45)の 4 式となる.

\section{6・2 $\theta=$ 一定時の接地点での転がり条件}

楕円体の溝斜面との接地点 $\mathrm{P}$ における滑り速度べクトルを $\boldsymbol{v}_{P}$ とすると， $\boldsymbol{v}_{P}$ は式(20)において，添字 $S_{S}$ の表記を ${ }_{P}$ に換えれば良いのだが， $x_{P}, y_{P}(=0), z_{P}$ は式(38)より一定值であり， $Z_{G}$ も式(40)より一定值をとるのでさらに簡単 化され

$$
\begin{aligned}
\boldsymbol{v}_{P}= & \left\{\dot{X}_{G}-\dot{\phi} \sin \phi \cos \theta_{0} x_{P}-\dot{\phi} \sin \theta_{0} \sin \phi z_{P}+\dot{\psi} \sin \phi z_{P}\right\} \boldsymbol{e}_{X} \\
& +\left\{\dot{Y}_{G}+\dot{\phi} \cos \phi \cos \theta_{0} x_{P}+\dot{\phi} \sin \theta_{0} \cos \phi z_{P}-\dot{\psi} \cos \phi z_{P}\right\} \boldsymbol{e}_{Y}
\end{aligned}
$$

となる.式(46)に $Z$ 成分は現れないので，接地点は溝斜面の $X Y$ 平面上を運動することになる。接地点 $\mathrm{P} て ゙$ 楕円 体が滑らないで転がる条件としては， $\boldsymbol{v}_{P}=\mathbf{0}$ であるから

$$
\begin{aligned}
& \dot{X}_{G}=\dot{\phi}\left(x_{P} \cos \theta_{0}+z_{P} \sin \theta_{0}\right) \sin \phi-z_{P} \dot{\psi} \sin \phi \\
& \dot{Y}_{G}=-\dot{\phi}\left(x_{P} \cos \theta_{0}+z_{P} \sin \theta_{0}\right) \cos \phi+z_{P} \dot{\psi} \cos \phi
\end{aligned}
$$

を得る. 式(47)の第一式 $\times \cos \phi+$ 第二式 $\times \sin \phi$ を作ると 


$$
\dot{X}_{G} \cos \phi+\dot{Y}_{G} \sin \phi=0
$$

となる．これは楕円体の重心速度が $x$ 軸方向成分を持たないことを示している.

さらに式(47)の第一式 $\times \sin \phi$ 一第二式 $\times \cos \phi$ を作ると，スピン角速度 $\mathrm{d} \psi / \mathrm{d} t$ が次式のように求められる.

$$
\dot{\psi}=\left(1 / z_{P}\right)\left\{\left(\dot{Y}_{G} \cos \phi-\dot{X}_{G} \sin \phi\right)+\left(x_{P} \cos \theta_{0}+z_{P} \sin \theta_{0}\right) \dot{\phi}\right\}
$$

\section{$6 \cdot 3$ 並進系及び回転系運動方程式を連立させた解 $\left(\theta=\theta_{0}\right)$}

この節では, $\theta=\theta_{0}$ の時の未知変数を算出するとともに, 運動方程式を数值解析で解くのに適した形（加速度 $=f($ 速度，変位 $) ）$ に変形させることにする.

未知変数である $X_{G}, Y_{G}, Z_{G}, \phi, \psi, L_{P}, M_{P}, N_{P}$ のうち, $Z_{G}, N_{P}$ については, $\theta=\theta_{0}$ の時には既に式 (40)及び式(41)によって既知量になっているので, 未知数は残りの 6 個になる. この場合は, $x_{P}, y_{P}(=0), z_{P}$ は式(38) より一定值をとることを考慮して，式(47)を時刻 $t$ で微分すると

$$
\begin{aligned}
& \left.\ddot{X}_{G}=\left(x_{P} \cos \theta_{0}+z_{P} \sin \theta_{0}\right) \ddot{\phi} \sin \phi+\dot{\phi}^{2} \cos \phi\right)-z_{P}(\ddot{\psi} \sin \phi+\dot{\psi} \dot{\phi} \cos \phi) \\
& \ddot{Y}_{G}=-\left(x_{P} \cos \theta_{0}+z_{P} \sin \theta_{0}\right)\left(\ddot{\phi} \cos \phi-\dot{\phi}^{2} \sin \phi\right)+z_{P}(\ddot{\psi} \cos \phi-\dot{\psi} \dot{\phi} \sin \phi)
\end{aligned}
$$

が得られる. 式(42)(43)(44)(45)と上式(50)(51)を連立させて, 未知数である $\mathrm{d}^{2} X_{G} / \mathrm{d} t^{2}, \mathrm{~d}^{2} Y_{G} / \mathrm{d} t^{2}, \mathrm{~d}^{2} \phi / \mathrm{d} t^{2}, \mathrm{~d}^{2} \psi / \mathrm{d} t^{2}$, $L_{P} / m, M_{P} / m$ を求めると次のようになる.

$$
\begin{aligned}
& \ddot{X}_{G}=\frac{m g \sin \beta \sin ^{2} \phi\left(A x_{P}^{2}+C z_{P}^{2}\right)}{\left\{\left(A+m z_{P}^{2}\right) C+m A x_{P}^{2}\right\}}-\dot{\phi} \cos \phi\left(\dot{Y}_{G} \cos \phi-\dot{X}_{G} \sin \phi\right) \\
& \ddot{Y}_{G}=\frac{-m g \sin \beta \sin \phi \cos \phi\left(A x_{P}^{2}+C z_{P}^{2}\right)}{\left\{\left(A+m z_{P}^{2}\right) C+m A x_{P}^{2}\right\}}-\dot{\phi} \sin \phi\left(\dot{Y}_{G} \cos \phi-\dot{X}_{G} \sin \phi\right) \\
& \ddot{\phi}=\frac{A x_{P} m g \sin \beta \sin \phi}{\left\{\left(A+m z_{P}^{2}\right) C+m A x_{P}^{2}\right\} \cos \theta_{0}} \\
& \ddot{\psi}=\frac{m g \sin \beta \sin \phi\left(-z_{P} C \cos \theta_{0}+x_{P} A \sin \theta_{0}\right)}{\left\{\left(A+m z_{P}^{2}\right) C+m A x_{P}^{2}\right\} \cos \theta_{0}} \\
& \frac{L_{P}}{m}=\frac{m g \sin \beta \sin { }^{2} \phi\left(A x_{P}^{2}+C z_{P}^{2}\right)}{\left\{\left(A+m z_{P}^{2}\right) C+m A x_{P}^{2}\right\}}-\dot{\phi} \cos \phi\left(\dot{Y}_{G} \cos \phi-\dot{X}_{G} \sin \phi\right)-g \sin \beta \\
& \frac{M_{P}}{m}=\frac{-m g \sin \beta \sin \phi \cos \phi\left(A x_{P}^{2}+C z_{P}^{2}\right)}{\left\{\left(A+m z_{P}^{2}\right) C+m A x_{P}^{2}\right\}}-\dot{\phi} \sin \phi\left(\dot{Y}_{G} \cos \phi-\dot{X}_{G} \sin \phi\right)
\end{aligned}
$$

結局, $\mathrm{d}^{2} \phi / \mathrm{d} t^{2}$ の式(54)， $\mathrm{d}^{2} X_{G} / \mathrm{d} t^{2}$ の式(52)， $\mathrm{d}^{2} Y_{G} / \mathrm{d} t^{2}$ の式(53)は， $\phi, X_{G}, Y_{G}$ に関する連立微分方程式として得 られたことになるので，例えばルンゲクッタ・ギル法等の数值解析を用いれば， $\phi, X_{G}, Y_{G}$ の時間変化が求め

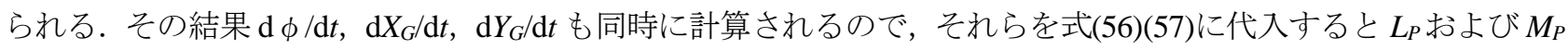
が求められ，式(49)に代入すると，楕円体のスピン角速度 $\mathrm{d} \psi / \mathrm{d} t$ も算出されることになる. 


\section{$6 \cdot 4$ ピッチング角 $\theta_{0}$ の推定法}

ここまでの $\theta$ は，重力の静的バランスから決まる角度 $\theta_{0}$ にほぼ等しいとして解いてきたが，その $\theta_{0}$ の具体的 表現を未だしていなかった. ここで $\theta_{0}$ を式として求めておく.

$y$ 軸回りのモーメント $T_{y}$ を示寸式(31)の第二式の右辺に, 式(56)の $L_{P}$, 式(57)の $M_{P}$, 式(41)の $N_{P}$ 及び式(47)の $\mathrm{d} X_{G} / \mathrm{d} t, \quad \mathrm{~d} Y_{G} / \mathrm{d} t$ を代入すると

$$
\begin{aligned}
T_{y}= & m \dot{\phi}\left\{\left(x_{P} \cos \theta+z_{P} \sin \theta\right) \dot{\phi}-z_{P} \dot{\psi}\right\}\left(-x_{P} \sin \theta+z_{P} \cos \theta\right) \\
& -m g\left\{x_{P}(-\sin \beta \cos \phi \sin \theta+\cos \beta \cos \theta)+z_{P}(\sin \beta \cos \phi \cos \theta+\cos \beta \sin \theta)\right\}
\end{aligned}
$$

と表されるので，重力による静的バランス時の $\theta$ を $\theta_{0}$ と記すことにすれば， $\theta_{0}$ は式(58)の第二項の \{\}$=0$ を満た している. 即ち

$$
\frac{x_{P}}{z_{P}}=\frac{\left(\sin \beta \cos \phi+\cos \beta \tan \theta_{0}\right)}{\left(\sin \beta \cos \phi \tan \theta_{0}-\cos \beta\right)}
$$

が成り立つ. 式(59)の左辺に式(38)を代入した後, $\tan \theta_{0}$ が小さいとして $\theta_{0}$ について解くと

$$
\theta_{0} \doteqdot \tan ^{-1}\left(\frac{\{(\varepsilon / b)+\tan \beta \cos \phi\}}{\left\{(a / b)^{2}-1+(\varepsilon / b) \tan \beta \cos \phi\right\}}\right)
$$

が得られる. 式(60)からわかるように $\theta_{0}$ は $\phi$ の関数となってはいるが, $\tan \beta$ の值も小さいので $\theta_{0}$ の変化分に与 える影響は小さい. そのため, ここでは $\phi=0$ の時の $\theta_{0}$ を $\theta$ の代表值として採用しても妥当であると考えた.

以上で, 楕円体が角溝の側面と衝突しない範囲で, 坂面上を滑らずに転がっていく時の挙動解析が出来たこと になる．次章以降では，楕円体が角溝の側面と衝突する際の挙動解析を行うことにする.

\section{7. 楕円体の溝側面との衝突に伴うカ積とカ積モーメント}

\section{$7 \cdot 1$ 衝突点の位置座標}

角溝内で転動している楕円体が，重心 $G$ 回りにオイラー角（ $\left.\phi ， \theta_{0} ， \psi\right)$ だけ回転した状態にある時, 溝側 面と平行な面 $\left(Y=Y_{Q}\right)$ とQ点で接するとする (図6参照).

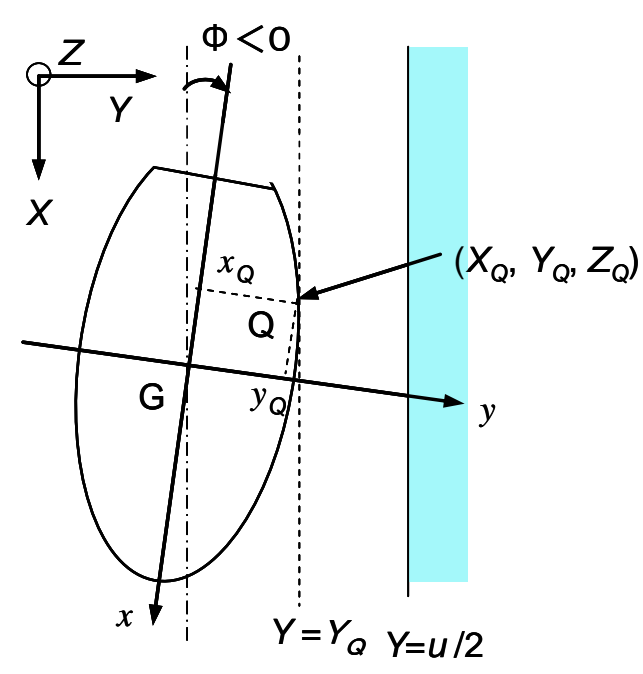

The case of $\Phi<0$

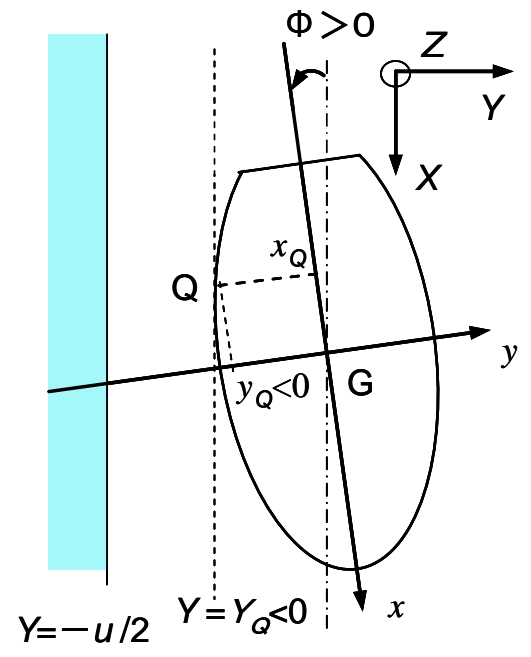

The case of $\Phi>0$

Fig.6 Surface point Q of the ellipsoidal body contacting with the plane which is in parallel with the side wall of a gutter. $Y= \pm u / 2$ means the position of a side wall. 
図 6 に示寸ように, Q点の位置座標として, 固定座標系 $\mathrm{O}-X Y Z$ から見た座標を $\left(X_{Q}, Y_{Q}, Z_{Q}\right)[\mathrm{m}]$ とし, 歳差運 動座標系 $\mathrm{G}-x y z$ から見た座標を $\left(x_{Q}, y_{Q}, z_{Q}\right)[\mathrm{m}]$ とする.ここで

$$
z_{Q}=0
$$

が成立している，Q点は楕円体表面上の点であるので， $\left(x_{Q}, y_{Q}, z_{Q}=0\right)$ は式(3)を満たしている，これより，次式 が成立している.

$$
\left(x_{Q}+\varepsilon\right)^{2}=a^{2}\left\{1-\left(y_{Q} / b\right)^{2}\right\}
$$

Q点において楕円体と接する, 溝側面と平行な平面の式は, 式(10)において添字 $s$ の表記を $Q$ に置き換えるとと もに, $\theta=\theta_{0}$ 及び $z_{Q}=0$ を代入した式で表される. 即ち

$$
\begin{aligned}
& \left(X-X_{Q}\right)\left\{\left(x_{Q}+\varepsilon\right) \cos \theta_{0} \cos \phi-(a / b)^{2} y_{Q} \sin \phi\right\} \\
& +\left(Y-Y_{Q}\right)\left\{\left(x_{Q}+\varepsilon\right) \cos \theta_{0} \sin \phi+(a / b)^{2} y_{Q} \cos \phi\right\}-\left(Z-Z_{Q}\right)\left(x_{Q}+\varepsilon\right) \sin \theta_{0}=0
\end{aligned}
$$

式(63)で示される接平面の式は, $Y=Y_{Q}$ を通る $X Z$ 平面の式になる訳だから, 任意の $X$ 及び $Z$ の值においても式(63) が成立する必要があるが, $Z$ は $Z_{G}$ の近傍のみで変化し， $\theta=\theta$ 。はモデルにも依るが式(60)よりせいぜい $5^{\circ}$ 以下 の值であり十分小さいので, 式(63)の最後の項は無視できるから

$$
\left(x_{Q}+\varepsilon\right) \cos \theta_{0} \cos \phi=(a / b)^{2} y_{Q} \sin \phi
$$

を得る. 式(64)の両辺を二乗した後，式(62)を代入すると次のようになる.

$$
\left(1-\frac{y_{Q}^{2}}{b^{2}}\right) \cos ^{2} \theta_{0}=\frac{a^{2}}{b^{4}} y_{Q}^{2} \tan ^{2} \phi
$$

これより $y_{Q}$ について解くと

$$
y_{Q}=\frac{ \pm b^{2} \cos \theta_{0}}{\sqrt{b^{2} \cos ^{2} \theta_{0}+a^{2} \tan ^{2} \phi}} \quad \text { （複号は } Y_{Q} \gtrless 0 \text { に対応している） }
$$

式(66)を式(62)に代入して， $x_{Q}$ について解くと

$$
x_{Q}=\frac{ \pm a^{2} \tan \phi}{\sqrt{b^{2} \cos ^{2} \theta_{0}+a^{2} \tan ^{2} \phi}}-\varepsilon \quad \text { (複号は } Y_{Q} \gtrless 0, y_{Q} \gtrless 0 \text { に対応している) }
$$

が得られる. $X_{Q}, Y_{Q}, Z_{Q}$ と $x_{Q}, y_{Q}, z_{Q}$ の間の関係は, 式(9)において添字 ${ }_{S}$ の表記を $Q$ に置き換え, $\theta=\theta_{0}$ 及び $z_{Q}=0$ を代入すると

$$
\begin{aligned}
& X_{Q}=X_{G}+x_{Q} \cos \theta_{0} \cos \phi-y_{Q} \sin \phi \\
& Y_{Q}=Y_{G}+x_{Q} \cos \theta_{0} \sin \phi+y_{Q} \cos \phi \\
& Z_{Q}=Z_{G}-x_{Q} \sin \theta_{0}
\end{aligned}
$$

の関係が得られる. 式(67)の $x_{Q}$, 式(66)の $y_{Q}$ を式(68)に代入すると, 固定座標系 $\mathrm{O}-X Y Z$ から見た $\mathrm{Q}$ 点の座標 $\left(X_{Q}, Y_{Q}, Z_{Q}\right)$ が求められる. 特に $Y_{Q}$ について具体的に記すと

$$
Y_{Q}=Y_{G} \pm \frac{\left(a^{2} \sin ^{2} \phi+b^{2} \cos ^{2} \phi\right) \cos \theta_{0}}{\cos \phi \sqrt{b^{2} \cos ^{2} \theta_{0}+a^{2} \tan ^{2} \phi}}-\varepsilon \cos \theta_{0} \sin \phi \quad \text { （複号は } y_{Q} \gtrless 0 \text { に対忘している） }
$$

となる．角溝の幅が $u$ であったので, 式(69)の $Y_{Q}$ の值が, $u / 2$ または一 $u / 2$ の值になった時, 楕円体は溝側面と

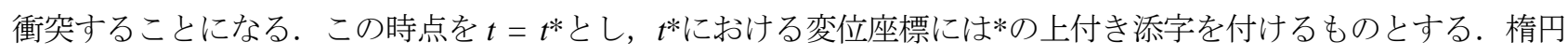
体が溝側面に衝突した際の $x_{Q}{ }^{*}, y_{Q}{ }^{*}, z_{Q}{ }^{*}$ は，式(67)(66)(61)において $\phi=\phi^{*}$ を代入したものとなる. また $Z_{G}{ }^{*}$ (三 $\left.Z_{G}\right)$ については式(40)で既に求められているので, 衝突時の $X_{G}{ }^{*}, Y_{G}{ }^{*}, Z_{G}{ }^{*}, \phi^{*}$ が決まれば, 式(68)より $X_{Q}{ }^{*}, Y_{Q}{ }^{*}$ 
$(= \pm u / 2), Z_{Q}{ }^{*}$ も求まる.これらにより衝突（直前）時の位置座標が全て求まったことになる.

\section{$7 \cdot 2$ 溝側面との衝突時の力積及び衝突前後の運動量の変化}

楕円体の角溝側面に衝突する時点 $\left(t=t^{*}\right)$ の前後における物理量（速度）にそれぞれダッシュ（'）及びッーダ ッシュ（”）を付けて区別するものとする. 図 7 に示すように，楕円体と溝側面との衝突点Qで発生した力積の うち $X$ 方向成分を $-R \Delta t[\mathrm{Ns}], Y$ 方向成分を $-S \Delta t[\mathrm{Ns}]$ とする．即ち力積が

$$
-R \Delta t \boldsymbol{e}_{X}-S \Delta t \boldsymbol{e}_{Y}
$$

と表現されるものとする. $Z$ 方向に力積が生じないのは，衝突時においても $Z$ 方向に滑りがなく，かつ $\theta=\theta_{0}$ （一定）が成立しているので, 式(40)より $Z_{G}=$ 一定となるからである.
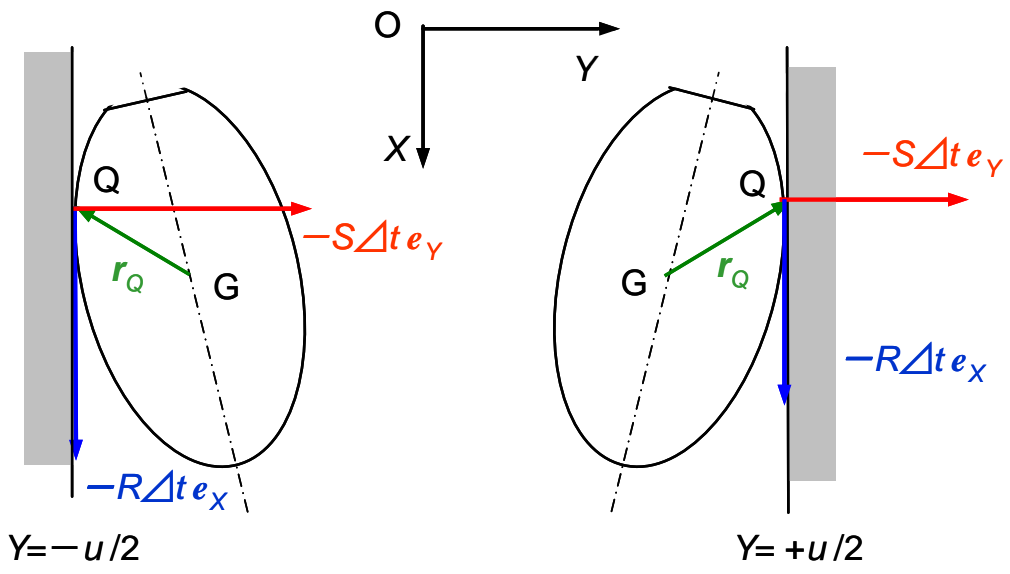

Fig.7 Impulsive forces generated between the rolling ellipsoidal body and the side wall of a gutter when they collide each other.

楕円体の衝突前後の運動量の差は式(70)で示された力積に等しい. 即ち

$$
-R \Delta t \boldsymbol{e}_{X}-S \Delta t \boldsymbol{e}_{Y}=m\left(\dot{\boldsymbol{R}}_{G}{ }^{\prime}-\dot{\boldsymbol{R}}_{G}{ }^{\prime}\right)
$$

が成立している．右辺の $\mathrm{d} \boldsymbol{R}_{G} " / \mathrm{d} t-\mathrm{d} \boldsymbol{R}_{G}^{\prime} / \mathrm{d} t$ は，式(1)より

$$
\dot{\boldsymbol{R}}_{G}{ }^{\prime}-\dot{\boldsymbol{R}}_{G}{ }^{\prime}=\left(\dot{X}_{G}{ }^{\prime}-\dot{X}_{G}{ }^{\prime}\right) \boldsymbol{e}_{X}+\left(\dot{Y}_{G}{ }^{\prime}-\dot{Y}_{G}{ }^{\prime}\right) \boldsymbol{e}_{Y}+\left(\dot{Z}_{G}{ }^{\prime}-\dot{Z}_{G}{ }^{\prime}\right) \boldsymbol{e}_{Z}
$$

と示されるが， $Z_{G}=$ 一定なので, $\mathrm{d} Z_{G}{ }^{\prime} / \mathrm{d} t=\mathrm{d} Z_{G}{ }^{\prime} / \mathrm{d} t=0$ となり，式(72)の右辺第三項は 0 となる. 式(72)を式(71) の右辺に代入して両辺を比較すると，次式が得られる.

$$
\left.\begin{array}{l}
-R \Delta t=m\left(\dot{X}_{G}{ }^{\prime}-\dot{X}_{G}{ }^{\prime}\right) \\
-S \Delta t=m\left(\dot{Y}_{G}{ }^{\prime}-\dot{Y}_{G}{ }^{\prime}\right)
\end{array}\right\}
$$

\section{$7 \cdot 3$ 溝側面との衝突前後の角運動量変化と衝突時のカ積モーメント}

楕円体の重心 $G$ 回りの角運動量ベクトル $L$ は既に式(32)で示されている.ただし今の場合 $\theta=\theta_{0}$ （一定）であ るから

$$
\boldsymbol{L}=A\left(\dot{\psi}-\dot{\phi} \sin \theta_{0}\right) \boldsymbol{e}_{x}+C \dot{\phi} \cos \theta_{0} \boldsymbol{e}_{z}
$$

と簡単化される．衝突前後の角運動量ベクトルの差を $\Delta L$ とすると，上式より

$$
\boldsymbol{\Delta} \boldsymbol{L}=A\left\{(\dot{\psi} "-\dot{\psi},)-\left(\dot{\phi}^{\prime}-\dot{\phi}{ }^{\prime}\right) \sin \theta_{0}\right\} \boldsymbol{e}_{x}+C(\dot{\phi} "-\dot{\phi},) \cos \theta_{0} \boldsymbol{e}_{z}
$$

と表される. 一方, 式(70)で示された力積によって楕円体の重心 $\mathrm{G}$ 点回りに作用する力積モーメントベクトルを $\Delta \boldsymbol{J}$ とすると 


$$
\Delta \boldsymbol{J}=\boldsymbol{r}_{Q} \times\left(-R \Delta t \boldsymbol{e}_{X}-S \Delta t \boldsymbol{e}_{Y}\right)
$$

と表される. $\boldsymbol{r}_{Q}$ は歳差運動座標系 $\mathrm{G}-x y z$ から見た衝突点Qの位置ベクトルであり, 式(7)において添字 $s$ の表記 を $Q$ に換えたものである. 即ち $z_{Q}{ }^{*}=0$ を考慮すると

$$
\boldsymbol{r}_{Q}=x_{Q}^{*} \boldsymbol{e}_{x}+y_{Q}^{*} \boldsymbol{e}_{y}
$$

と表される．式(77)を式(76)に代入した後，式(5)の関係を用いて整理すると

$$
\begin{aligned}
\Delta \boldsymbol{J} & =\left(R \Delta t \cos \phi^{*}+S \Delta t \sin \phi^{*}\right) \sin \theta_{0}\left(-y_{Q}{ }^{*} \boldsymbol{e}_{x}+x_{Q}{ }^{*} \boldsymbol{e}_{y}\right) \\
& +\left\{\left(R \Delta t\left(x_{Q}{ }^{*} \sin \phi^{*}+y_{Q}{ }^{*} \cos \phi^{*} \cos \theta_{0}\right)+S \Delta t\left(-x_{Q}{ }^{*} \cos \phi^{*}+y_{Q}{ }^{*} \sin \phi^{*} \cos \theta_{0}\right)\right\} \boldsymbol{e}_{z}\right.
\end{aligned}
$$

を得る. 衝突時点である $t=t$ *における力積モーメントベクトル $\Delta \boldsymbol{J}$ は, 式(75)で示された角運動量ベクトルの変 化分 $\Delta L$ に等しい. 即ち式(75)と式(78)の右辺同士を等しく置き, $\boldsymbol{e}_{x}, \boldsymbol{e}_{y}, \boldsymbol{e}_{z}$ の係数を等しく置くと次の三式が得 られる.

$$
\begin{aligned}
& A\left\{(\dot{\psi} "-\dot{\psi},)-\left(\dot{\phi}^{\prime}-\dot{\phi}^{\prime}\right) \sin \theta_{0}\right\}=-y_{Q}{ }^{*}\left(R \Delta t \cos \phi^{*}+S \Delta t \sin \phi^{*}\right) \sin \theta_{0} \\
& x_{Q}{ }^{*}\left(R \Delta t \cos \phi^{*}+S \Delta t \sin \phi^{*}\right) \sin \theta_{0}=0 \\
& C\left(\dot{\phi} "-\dot{\phi}{ }^{\prime}\right) \cos \theta_{O}=x_{Q}{ }^{*}\left(R \Delta t \sin \phi^{*}-S \Delta t \cos \phi^{*}\right)+y_{Q}{ }^{*}\left(R \Delta t \cos \phi^{*}+S \Delta t \sin \phi^{*}\right) \cos \theta_{0}
\end{aligned}
$$

ところで式(79)は，接地点 $\mathrm{P} て ゙$ 楕円体が浮き上がったと仮定した上での衝突後におけるスピン角速度 $\mathrm{d} \psi " / \mathrm{d} t$ を決める式に相当しているが, 衝突時には楕円体は接地点 $\mathrm{P}$ と衝突点 $\mathrm{Q}$ の二点で角溝と接触する形になっており, 実験でも衝突直後のスピン角速度 $\mathrm{d} \psi " / \mathrm{d} t$ が一瞬停止するのが観察された. これらの事より式(79)の代わりに

$$
\dot{\psi} "=0
$$

が条件として加わることになる，一方，式(49)より $\mathrm{d} \psi ” / \mathrm{d} t=0$ になる時は

$$
\dot{\phi} "=\frac{\left(\dot{X}_{G} " \sin \phi^{*}-\dot{Y}_{G} " \cos \phi^{*}\right)}{\left(x_{P} \cos \theta_{0}+z_{P} \sin \theta_{0}\right)}
$$

が成立することになる.さらに式(80)を考慮すると,式(81)の右辺の第二項は 0 になるので

$$
C(\dot{\phi} "-\dot{\phi} ') \cos \theta_{0}=x_{Q}{ }^{*}\left(R \Delta t \sin \phi^{*}-S \Delta t \cos \phi^{*}\right)
$$

が得られる. また式(80) (84)を式(78)に代入すると, 力積モーメント $\Delta \boldsymbol{J}$ は最終的に次式のように表現される.

$$
\boldsymbol{\Delta} \boldsymbol{J}=\boldsymbol{\Delta} \boldsymbol{L}=C(\dot{\phi} "-\dot{\phi},) \cos \theta_{0} \boldsymbol{e}_{z}
$$

未知変数である角溝側面との衝突直後の速度 $\mathrm{d} X_{G}{ }^{\prime} / \mathrm{d} t, \mathrm{~d} Y_{G}{ }^{\prime} / \mathrm{d} t, \mathrm{~d} \phi " / \mathrm{d} t, \mathrm{~d} \psi " / \mathrm{d} t$ 及び衝突時の力積 $R \Delta t, S \Delta t$ を求めるには，上記式群(73)（80）(83）(84）だけでは不足しており, 衝突点Qでの楕円体と側壁との間の反発係数 $e$ を用いた関係式が必要であり, 次の第 8 章で関連式を導くことにする.

\section{8. 衝突時の棈円体速度の変化と衝突直後の物理量の導出}

\section{$8 \cdot 1$ 衝突前後におけるQ点の速度変化}

衝突時 $\left(t=t^{*}\right)$ における楕円体上Q点の速度ベクトルを $\boldsymbol{v}_{Q}$ とすると, $\boldsymbol{v}_{Q}$ は式(20)において添字 $s$ の表記を $Q$ に 置き換えるとともに, $\theta=\theta_{0}, \phi=\phi^{*}, z_{Q}{ }^{*}=0$ 及び $\mathrm{d} Z_{G} / \mathrm{d} t=0$ を代入すると

$$
v_{Q}=v_{Q X} \boldsymbol{e}_{X}+v_{Q Y} \boldsymbol{e}_{Y}+v_{Q Z} \boldsymbol{e}_{Z}
$$


と表される.ここに $v_{Q X}[\mathrm{~m} / \mathrm{s}], v_{Q Y}[\mathrm{~m} / \mathrm{s}], v_{Q Z}[\mathrm{~m} / \mathrm{s}]$ は

$$
\begin{aligned}
v_{Q X} & =\dot{X}_{G}+\dot{x}_{Q} \cos \theta_{0} \cos \phi^{*}-\dot{y}_{Q} \sin \phi^{*}-x_{Q}{ }^{*} \dot{\phi} \sin \phi^{*} \cos \theta_{0}+y_{Q}{ }^{*}\left(\dot{\psi} \sin \theta_{0}-\dot{\phi}\right) \cos \phi^{*} \\
v_{Q Y} & =\dot{Y}_{G}+\dot{x}_{Q} \cos \theta_{0} \sin \phi^{*}+\dot{y}_{Q} \cos \phi^{*}+x_{Q}{ }^{*} \dot{\phi} \cos \phi^{*} \cos \theta_{0}+y_{Q}{ }^{*}\left(\dot{\psi} \sin \theta_{0}-\dot{\phi}\right) \sin \phi^{*} \\
v_{Q Z} & =-\dot{x}_{Q} \sin \theta_{0}+y_{Q}{ }^{*} \dot{\psi} \cos \theta_{0}
\end{aligned}
$$

である. 式(87)は $t=t^{*}$ の棈円体の溝側面との衝突時の物理量（変位, 速度）の関係を示しているが, $x_{Q}{ }^{*}, y_{Q}{ }^{*}, \phi^{*}$ は衝突前後で変化しないのに対して, $\mathrm{d} X_{G} / \mathrm{d} t, \mathrm{~d} Y_{G} / \mathrm{d} t, \mathrm{~d} x_{Q} / \mathrm{d} t, \mathrm{~d} y_{Q} / \mathrm{d} t, \mathrm{~d} \phi / \mathrm{d} t, \mathrm{~d} \psi / \mathrm{d} t$ つまり $v_{Q X}, v_{Q Y}, v_{Q Z}$ は衝突 前後で変化することになる. 式(87)中の $\mathrm{d} x_{Q} / \mathrm{d} t, \mathrm{~d} y_{Q} / \mathrm{d} t$ は, 具体的には式(67)(66)を時刻 $t$ で微分した後 $\phi=\phi^{*}$ とお けば

$$
\left.\begin{array}{l}
\dot{x}_{Q}=\frac{ \pm a^{2} b^{2} \dot{\phi} \cos ^{2} \theta_{0}}{\cos ^{2} \phi^{*}\left(b^{2} \cos ^{2} \theta_{0}+a^{2} \tan ^{2} \phi^{*}\right)^{3 / 2}} \\
\dot{y}_{Q}=\frac{\mp a^{2} b^{2} \dot{\phi} \cos \theta_{0} \sin \phi^{*}}{\cos ^{3} \phi^{*}\left(b^{2} \cos ^{2} \theta_{0}+a^{2} \tan ^{2} \phi^{*}\right)^{3 / 2}}
\end{array}\right\} \quad \text { (複号は } y_{Q}^{*} \gtrless 0 \text { に対応) }
$$

となる. $x_{Q}{ }^{*}, y_{Q}{ }^{*}$ 及び式(88)を式(87)の第二式に代入した後, $\mathrm{d} \phi / \mathrm{d} t$ を $\mathrm{d} \phi ' / \mathrm{d} t$ に, $\mathrm{d} \psi / \mathrm{d} t$ を $\mathrm{d} \psi{ }^{\prime} / \mathrm{d} t$ に $\mathrm{d} Y_{G} / \mathrm{d} t$ を $\mathrm{d} Y_{G}{ }^{\prime} / \mathrm{d} t$ に置き換えれば，Q点の衝突直前の $Y$ 方向速度（ $\left.v_{Q Y}{ }^{\prime}[\mathrm{m} / \mathrm{s}]\right)$ を求めることができる. 即ち

$$
\begin{aligned}
v_{Q Y}{ }^{\prime}= & \dot{Y}_{G}{ }^{\prime} \mp \frac{a^{2} b^{2} \sin ^{2} \theta_{0} \cos \theta_{0} \sin \phi^{*} \dot{\phi}^{\prime}}{\cos ^{2} \phi^{*}\left(b^{2} \cos ^{2} \theta_{0}+a^{2} \tan ^{2} \phi^{*}\right)^{3 / 2}}-\varepsilon \dot{\phi}^{\prime} \cos \theta_{0} \cos \phi^{*} \\
& \pm \frac{\sin \phi^{*} \cos \theta_{0}}{\sqrt{b^{2} \cos ^{2} \theta_{0}+a^{2} \tan ^{2} \phi^{*}}}\left\{\left(a^{2}-b^{2}\right) \dot{\phi}{ }^{\prime}+b^{2} \dot{\psi}{ }^{\prime} \sin \theta_{0}\right\} \quad \text { (複号は } y_{Q}^{*} \gtrless 0 \text { に対応) }
\end{aligned}
$$

が得られる. さらに側面との衝突直後の楕円体上 $Q$ 点の速度の $Y$ 方向速度を $v_{Q Y}$ ” $[\mathrm{m} / \mathrm{s}]$ として, 溝側面との反発 係数を $e$ とすれば

$$
v_{Q Y} "=-e v_{Q Y},
$$

が成立している. $v_{Q Y} ”$ は式(89)において（'）を（”）に換えたものである. 式(82)の $\mathrm{d} \psi ” / \mathrm{d} t=0$ を考慮して $v_{Q Y} ” を$ 求めた後, その $v_{Q Y} ”$ と式(89)の $v_{Q Y}$, を式(90)に代入して整理すると, 次式が得られる.

$$
\dot{Y}_{G}{ }^{\prime}=-\dot{e}_{G}{ }^{\prime}+\alpha_{1}\left(\dot{\phi} "+e \dot{\phi}{ }^{\prime}\right)+\alpha_{2} e \dot{\psi},
$$

ここに $\alpha_{1}, \alpha_{2}$ は次式で定義された量である.

$$
\left.\begin{array}{l}
\alpha_{1}=\frac{a^{2} b^{2} \sin ^{2} \theta_{0} \cos \theta_{0} \sin \phi^{*} \operatorname{sign}\left(y_{Q}^{*}\right)}{\cos ^{2} \phi^{*}\left(b^{2} \cos ^{2} \theta_{0}+a^{2} \tan ^{2} \phi^{*}\right)^{3 / 2}}+\varepsilon \cos \theta_{0} \cos \phi^{*}-\frac{\sin \phi^{*} \cos \theta_{0}\left(a^{2}-b^{2}\right) \operatorname{sign}\left(y_{Q}^{*}\right)}{\sqrt{b^{2} \cos ^{2} \theta_{0}+a^{2} \tan ^{2} \phi^{*}}} \\
\alpha_{2}=-\frac{\sin \phi^{*} \sin \theta_{0} \cos \theta_{0} b^{2} \operatorname{sign}\left(y_{Q}{ }^{*}\right)}{\sqrt{b^{2} \cos ^{2} \theta_{0}+a^{2} \tan ^{2} \phi^{*}}}
\end{array}\right\}
$$

\section{$8 \cdot 2$ 溝側面との衝突直後の速度及び衝突時の力積の算出}

式(73)(80)(82)(83)(84)及び(91)を連立させて, 未知数である側面衝突直後の速度 $\mathrm{d} X_{G}{ }^{\prime \prime} / \mathrm{d} t, \mathrm{~d} Y_{G}{ }^{\prime \prime} / \mathrm{d} t, \mathrm{~d} \phi " / \mathrm{d} t, \mathrm{~d} \psi " / \mathrm{d} t$ 及び衝突時の力積 $R \Delta t, S \Delta t$ を求めると以下のようになる. 


$$
\begin{aligned}
& \dot{\phi} "=\frac{\left\{-m x_{Q}{ }^{*}(1+e) \dot{Y}_{G}{ }^{\prime}+\left(C \cos \theta_{0} \cos \phi^{*}+m x_{Q}{ }^{*} \alpha_{1} e\right) \dot{\phi}^{\prime}+m x_{Q}{ }^{*} \alpha_{2} e \dot{\psi}^{\prime}\right\}}{\left(C \cos \theta_{0} \cos \phi^{*}-m x_{Q}{ }^{*} \alpha_{1}\right)} \\
& \dot{X}_{G} "=\cos \phi^{*}\left(\dot{X}_{G}{ }^{\prime} \cos \phi^{*}+\dot{Y}_{G}{ }^{\prime} \sin \phi^{*}\right)+\left(x_{P} \cos \theta_{0}+z_{P} \sin \theta_{0}\right) \dot{\phi}^{\prime \prime} \sin \phi^{*} \\
& \dot{Y}_{G} "=\sin \phi^{*}\left(\dot{X}_{G}{ }^{\prime} \cos \phi^{*}+\dot{Y}_{G}{ }^{\prime} \sin \phi^{*}\right)-\left(x_{P} \cos \theta_{0}+z_{P} \sin \theta_{0}\right) \dot{\phi}^{\prime \prime} \cos \phi^{*} \\
& \dot{\psi}^{\prime \prime}=0 \\
& R \Delta t=\frac{C \cos \theta_{0} \sin \phi^{*} m\left\{-(1+e) \dot{Y}_{G}{ }^{*}+\alpha_{1}(1+e) \dot{\phi}^{\prime}+\alpha_{2} e \dot{\psi}^{\prime}\right\}}{\left(C \cos \theta_{0} \cos \phi^{*}-m x_{Q}{ }^{*} \alpha_{1}\right)} \\
& S \Delta t=\frac{-C \cos \theta_{0} \cos \phi^{*} m\left\{-(1+e) \dot{Y}_{G}{ }^{\prime}+\alpha_{1}(1+e) \dot{\phi}{ }^{\prime}+\alpha_{2} e \dot{\psi}^{\prime}\right\}}{\left(C \cos \theta_{0} \cos \phi^{*}-m x_{Q}{ }^{*} \alpha_{1}\right)}
\end{aligned}
$$

即ち，これらの物理量が，溝側面との衝突直前の物理量 $\mathrm{d} X_{G}{ }^{\prime} / \mathrm{d} t, \mathrm{~d} Y_{G}{ }^{\prime} / \mathrm{d} t, \mathrm{~d} \phi \% / \mathrm{d} t, \mathrm{~d} \psi{ }^{\prime} / \mathrm{d} t$ と衝突時の位置座標 $x_{Q}{ }^{*}, \phi^{*}$ 及び $\alpha_{1}, \quad \alpha_{2}$ でもつて表されたことになる.これらのうち, 式(93)の $\mathrm{d} \phi \% / \mathrm{d} t$, 式(94)の $\mathrm{d} X_{G}{ }^{\prime} / \mathrm{d} t$, 式(95) の $\mathrm{d} Y_{G}{ }^{\prime} / \mathrm{d} t$ の值を初期速度值として, 再度転がり運動の方程式である式(52)(53)(54)を連立させて解けば, 角溝側面 と衝突した後の転動運動が求まることになる．以降これらの解析手順を続けていけば，角溝側面と衝突を繰り返 しながら斜面を転動する楕円体の運動の時間的変化が求められる. 次の第 9 章で実際のモデルを用いた解析結果 を示すことにする.

\section{9. 数值解析}

\section{$9 \cdot 1$ 数值解析及び実験で用いた楕円体と角溝の諸元}

解析及び実験で用いた転動する回転楕円体（木製）の三つのモデルの諸元を表 1 に示した. モデル I は長半径 $a$ が短く, 少し「ずんぐり」した形状の楕円体であり, モデル II, III は後端部が切り取られた砲弾型の形状をし ている. 一方，角溝 (木製) については，全長が $0.45 \mathrm{~m}$ であり，斜面の傾斜角は $\beta=8^{\circ} \quad(=0.14 \mathrm{rad})$ に固定した. 角溝の側壁高さは $21 \mathrm{~mm}$ と一定だが，溝幅は $u=49 \mathrm{~mm}$ 及び $u=44 \mathrm{~mm}$ の二種類とした. いずれの楕円体モデルで も $2 b<u<2 a$ であるので，楕円体が転動すると溝側壁と干渉し合うことになる.

Table 1 Specific items of three models of the ellipsoidal body utilized in the experimental device.

\begin{tabular}{l|l|l|l}
\hline \hline Model of ellipsoidal body & Model I & Model II & Model III \\
\hline $\begin{array}{l}\text { Outer configuration of the rolling } \\
\text { ellipsoidal body model }\end{array}$ & & & \\
\hline Length of semi-major axis: $a[\mathrm{~m}]$ & 0.0265 & 0.038 & 0.033 \\
\hline Length of semi-minor axis: $b[\mathrm{~m}]$ & 0.019 & 0.017 & 0.0185 \\
\hline $\begin{array}{l}\text { Distance between the backward end and } \\
\text { the geometric center }: c[\mathrm{~m}]\end{array}$ & $0.0265(c=a)$ & 0.030 & 0.027 \\
\hline Mass of ellipsoidal body $: m[\mathrm{~kg}]$ & 0.040 & 0.030 & 0.033 \\
\hline
\end{tabular}




\section{$9 \cdot 2$ 解析条件}

表 1 に示した諸元を有した楕円体モデル I， II ，IIIに関して数值解析を行った．側壁との衝突のない転がり期 間の挙動解析については, ルンゲクッタ・ギル法による解析を行った $(6 \cdot 3$ 節\& $8 \cdot 2$ 節参照 $)$. 用いた解析条件 は以下の通りである.

溝斜面の傾斜角 : $\beta=8^{\circ}$, 角溝幅 : $u=49 \mathrm{~mm}$ 及び $44 \mathrm{~mm}$, 楕円体・側壁間反発係数 : $e=0.7$ (0.4), 転がり期間 時間刻夕 $2 \mathrm{~ms}$, 側壁との衝突時間刻夕： $\Delta t=1 \mathrm{~ms}, t=0 \mathrm{~s}$ における初期角度 : $\phi=-10^{\circ}, \theta=\theta_{0}, \psi=0$, 重心初期 位置 : $X_{G}=0, Y_{G}=0$, 初期角速度 : $\mathrm{d} \phi / \mathrm{d} t=-0.02 \mathrm{rad} / \mathrm{s}$, 重心初期速度 : $\mathrm{d} X_{G} / \mathrm{d} t=0, \mathrm{~d} Y_{G} / \mathrm{d} t=0$

\section{$9 \cdot 3$ 数值解析結果}

（1）転動衝突運動の継続性確認

各モデルについて, 前記条件の下で転動衝突運動が反復して継続するかどうか解析した結果を○×表記で表 2 に示した．また転動衝突運動は $|\mathrm{d} \phi \% / \mathrm{d} t-\mathrm{d} \phi \% / \mathrm{d} t|$ が大きいほど継続すると考えられる。この事と式(85)から衝突 運動の継続性評価の指標として, 力積モーメントの大きさ $|\Delta \boldsymbol{J}|$ が適していると思われたので同表に併記した.

Table 2 Results of the numerical analysis (Repetition of impact and moment of impulse $|\Delta \boldsymbol{J}|$ ).

\begin{tabular}{l|l|l|l}
\hline \hline Model of ellipsoidal body & Model I & Model II & Model III \\
\hline $\begin{array}{l}\text { Repetitious behavior of impact } \\
\text { in the case } u=49 \mathrm{~mm}\end{array}$ & $\times$ & $\bigcirc$ & $\bigcirc$ \\
\hline $\begin{array}{l}\text { Repetitious behavior of impact } \\
\text { in the case } u=44 \mathrm{~mm}\end{array}$ & $\times \boldsymbol{J} \mid=1.71 \times 10^{-6} \mathrm{Nms}$ & $|\Delta \boldsymbol{J}|=3.78 \times 10^{-5} \mathrm{Nms}$ & $|\Delta \boldsymbol{J}|=4.13 \times 10^{-5} \mathrm{Nms}$ \\
\hline
\end{tabular}

表 2 より，転動衝突運動の継続性と力積モーメントの大きさ $|\Delta \boldsymbol{J}|$ とは関連性があることがわかる．即ち

(a)「ずんぐり」形のモデル I については， $u=49 \mathrm{~mm}, 44 \mathrm{~mm}$ どちらの場合でも, 溝側面とほんの 1,2 回衝突 寸るだけで停止する解になった. これは, 長半径 $a$ が小さく短軸長さ $2 b$ が溝幅 $u$ と比較して大きいので, 側面との衝突速度が小さく発生する力積モーメントも小さ過ぎるために，すぐに楕円体が側面と接した形 のままで停止してしまったと推定している.

（b）「砲弾型楕円体」であるモデル II については， $u=49 \mathrm{~mm}, 44 \mathrm{~mm}$ どちらの場合でも，溝側面との反復的衝突 運動を繰り返すという解となった．これはモデル I と比較して長半径 $a$ が大きく, 短軸長さ $2 b$ が溝幅 $u$ と比較して小さいので，側面との衝突速度が大きくなり，側面との衝突時に発生する力積モーメントも大 きくなるためと判断している.ただし反発係数 $e$ を,これまでの 0.7 から 0.4 まで小さくしてみると, $u=49 \mathrm{~mm}$ の時 $|\Delta \boldsymbol{J}|=2.07 \times 10^{-5} \mathrm{Nms}$ と小さくなり，転がり途中で衝突が生じなくなり停止するという解となった.

(c) モデルIII も「砲弾型楕円体」であるが，数值解析では $u=49 \mathrm{~mm}$ の場合は転がり衝突運動を繰り返す解と なったが， $u=44 \mathrm{~mm}$ の場合は転がり途中で衝突が生じなくなり停止するという解となった. 後者の場合, 力積モーメントの大きさがモデルII の值の半分以下の小さい值であるために途中で停止したと思われる. 表 2 は衝突運動継続の成否の理論的判別表になっており，後述の実験結果と対比することになる.

（2）楕円体の重心及びヨーイング角の変化

$u=49 \mathrm{~mm}$ の場合におけるモデル II の重心の座標 $\left(X_{G}, Y_{G}\right)$ 及びヨーイング角（ $\phi ）$ の時間的変化を図 8 に示 した．図からもわかるように，楕円体は転動しながら角溝の側面と衝突して，ヨーイング角の正負の切り替えを 繰り返しつつ斜面を下っていく様子が読み取れる. 細かく見ると，| $\mid$ |が漸増しているものの大きくは変化して いない期間があるが，そこでは $Y_{G}$ が異符号側に変化しているので，楕円体は側壁との衝突後 $x$ 軸回りのスピン回 転をしながら, 反対側の側面に衝突するまで, 溝坂面をほぼ斜め平行に転がっていく挙動を示していることがわ かる.

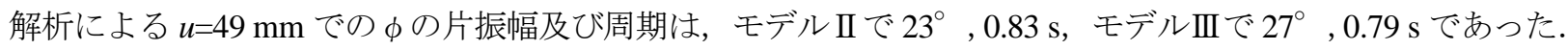




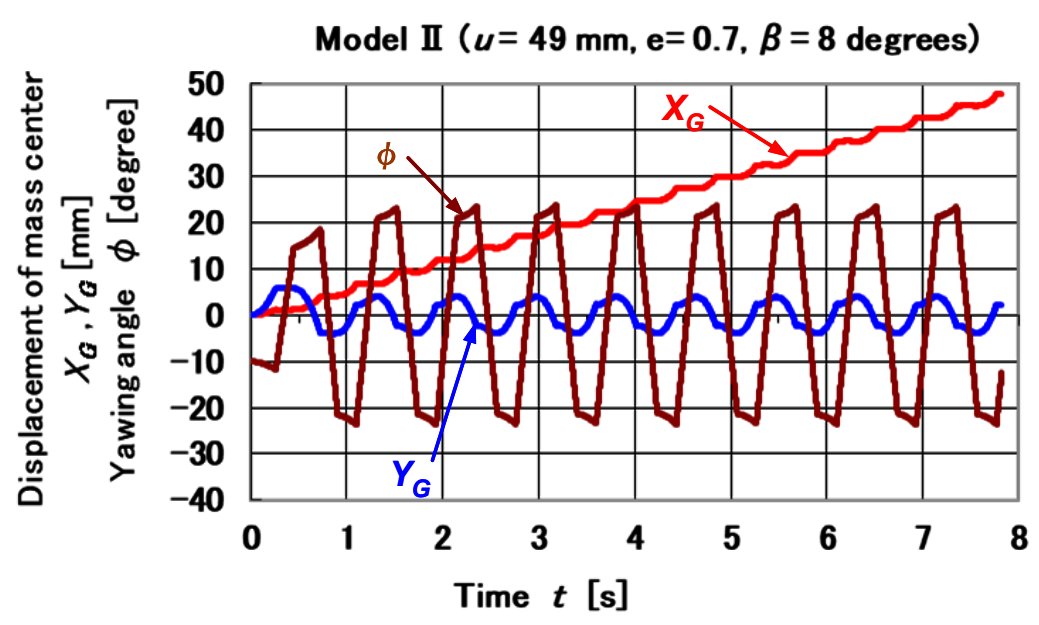

Fig.8 Passing variation of the position of the mass center and the yawing angle which represent the posture of the rolling ellipsoidal body (model II , $u=49 \mathrm{~mm}$ ).

\section{（3）二重衝突運動の発生}

図 9 は $u=49 \mathrm{~mm}$ の時のモデル II の角溝側面に対向した平行面に接する楕円体表面の点 $\mathrm{Q} の ~ Y$ 座標（ $Y_{Q} ）$ の時 間変化を示している. $Y_{Q}= \pm u / 2$ で両者が衝突することになる. 楕円体が角溝側面と衝突した直後に同じ面と再度 小さな衝突をしていることがわかる.これは図 8 と図 9 を対比させるとわかるように, 棈円体の重心の $Y$ 座標 $\left(Y_{G}\right)$ の変化に伴う並進運動により，睢壁との再度の衝突が生じていると解勫している.

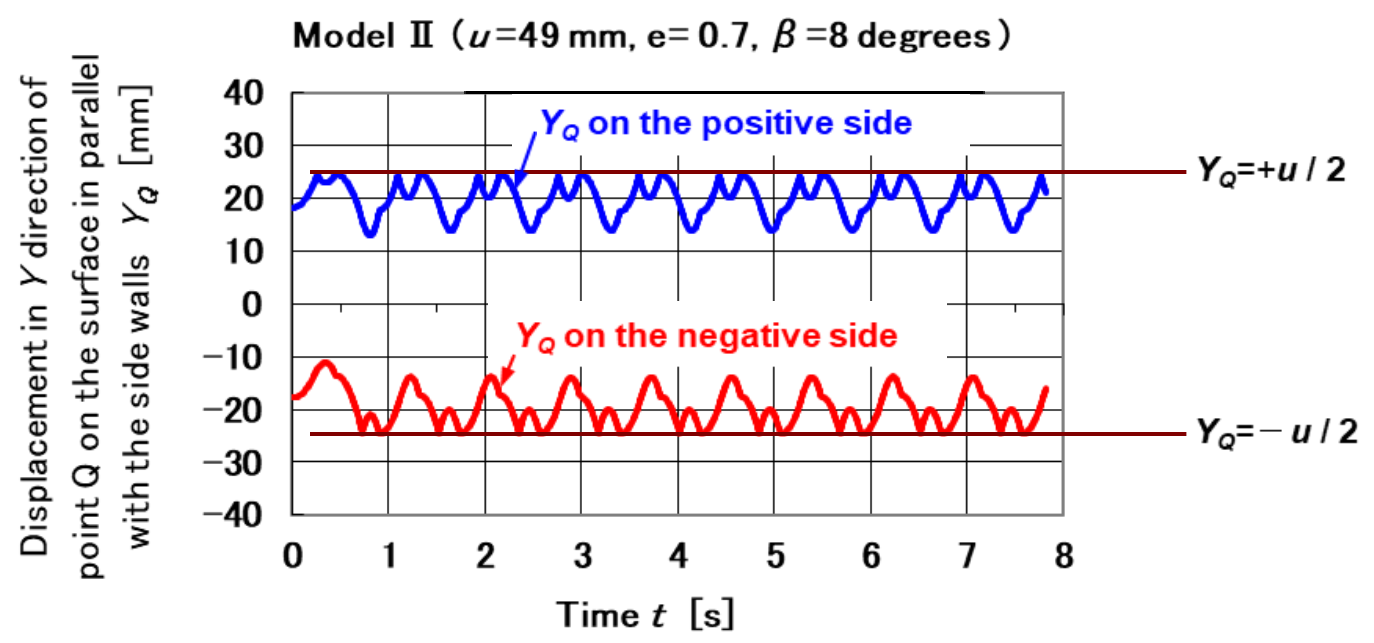

Fig.9 Displacement in $Y$ direction of the point $\mathrm{Q}$ on the ellipsoidal surface facing the side wall of a gutter. When $Y_{Q}$ equals $\pm u / 2$, collision between the ellipsoid and the side wall occurs. We can recognize that slight collision is brought about again after the main impact.

(4) 接地点 $\mathrm{P}$ における抗力の変化

モデル II の $u=49 \mathrm{~mm}$ の場合の楕円体と斜面との接地点 $\mathrm{P}$ における抗力 $L_{P}, M_{P}, N_{P}$ を図 10 に示した. 抗力 $N_{P}$ は 式(41)より一定であり， $M_{P}\left(=m \mathrm{~d}^{2} Y_{G} / \mathrm{d} t^{2}\right)$ は正負に変動している. 一方， $L_{P}$ は常に負の值であるので $-X$ 軸方向に 作用していることがわかる.

また静止摩擦係数に相当寸る $\left(L_{P}^{2}+M_{P}^{2}\right)^{1 / 2} / N_{P}$ も併せて同図に示したが，この值は 0.13 程度であり，実験装置の 両者（木材）間の最大静止摩擦係数（0.3〜0.4 程度）よりも小さい值であるので, 接地点 $\mathrm{P}$ で楕円体は常に滑ら ずに転がるだけになることがわかる，これは解析で仮定した前提条件である $\boldsymbol{v}_{P}=\mathbf{0}$ 及び式(47)と符合している. 
（5）楕円体重心の軌跡

図 11 は転動するモデル II の楕円体の重心座標（ $\left.X_{G}, Y_{G}\right)$ の軌跡を示したものである. 図からわかるように側壁 との衝突運動を繰り返しながら，うまく角溝斜面を下っていく様子が読み取れる.

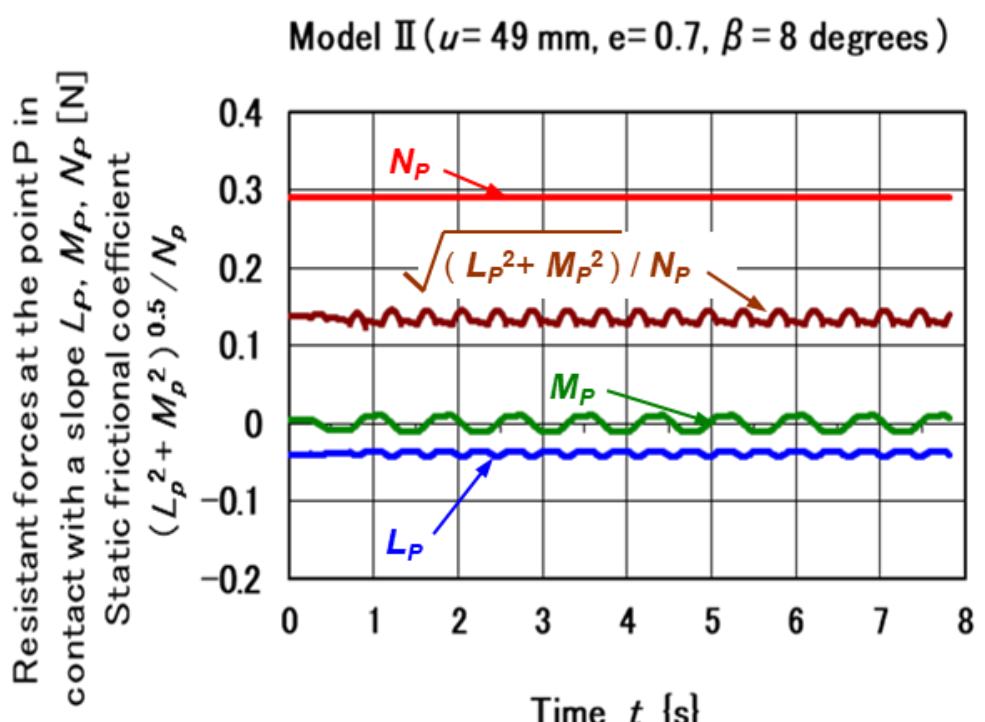

Time $t\{\mathbf{s}\}$

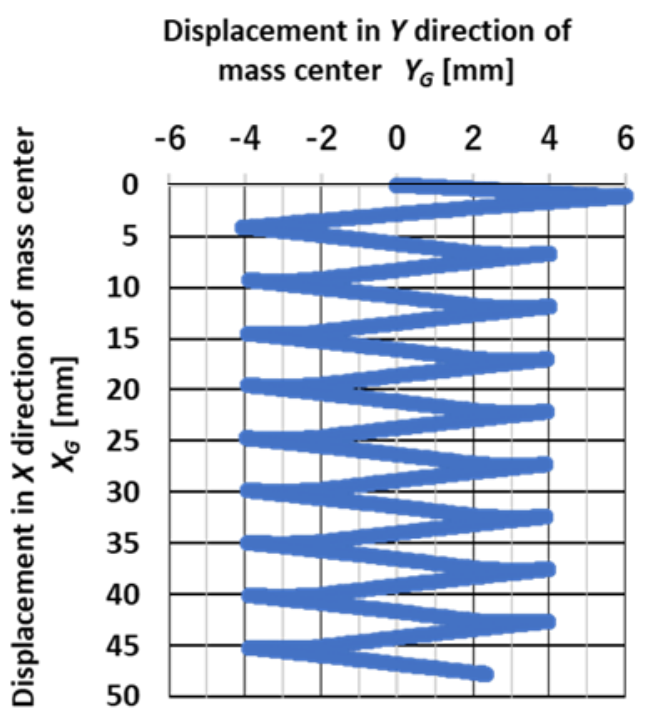

Fig.11 Locus of the center of gravity of the ellipsoidal body (model II , $u=49 \mathrm{~mm}$ ). We can recognize the repetitious colliding motion of the rolling body.

\section{0. 実験による反復衝突の検証}

表 1 で示された諸元を有した楕円体\&角溝系において, 初期条件として, $t=0 \mathrm{~s}$ において $\phi=-10^{\circ}$ から出発さ せた楕円体の転がり衝突運動の反復性を観察した。モデル I ではほんの数回溝側面と衝突したものの, 以降転が り運動はせず停止してしまった。一方モデル II は，溝幅 $u$ が $49 \mathrm{~mm}$ 及び $44 \mathrm{~mm}$ いずれの場合も溝側面との反復 的衝突運動を繰り返しながら，坂面の最後まで下っていった．モデルIIIについては，溝幅 $u$ が $49 \mathrm{~mm}$ の場合は坂 面の最後まで反復的衝突運動を繰り返したが, 溝幅 $u$ が $44 \mathrm{~mm}$ の場合は途中で転がり運動は停止してしまった. これらの結果を表 3 に示した．結局，実験においても解析で得られた判別表（表 2）と同じ結果が得られた.

Table 3 Results of the experiments (Repetition of impact).

\begin{tabular}{l|l|l|l}
\hline \hline Model of ellipsoidal body & Model I & Model II & Model III \\
\hline Repetitious behavior of impact in the case $u=49 \mathrm{~mm}$ & $\times$ & $\bigcirc$ & $\bigcirc$ \\
\hline Repetitious behavior of impact in the case $u=44 \mathrm{~mm}$ & $\times$ & $\bigcirc$ & $\times$ \\
\hline
\end{tabular}

その他実験により判明した点として， $u=49 \mathrm{~mm}$ の時モデル II ， III とも，楕円体が一度溝側面と衝突した直後に 同じ側面と再度かすかな衝突を起こしていることが解析と同様に実験でも観察された。ヨーイング運動（ $\phi ）$ の 片振幅及び周期は，平均してモデル II で $22^{\circ}, 0.77 \mathrm{~s}$ ，モデルIII で $26.5^{\circ}, 0.81 \mathrm{~s}$ であった．これらの值は，数值解

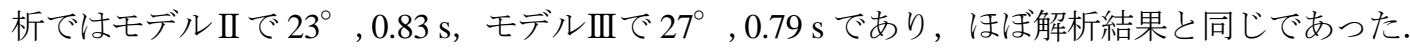




\section{1. 結}

回転楕円体モデルが傾斜した角溝内を転がりながら, 溝側面と反復的衝突運動を繰り返す挙動を, 実験と数值 解析の両方で検証した．その結果，次のような事柄が明らかになった.

（1）諸元の異なった楕円体が角溝内で溝側面との衝突を繰り返しながら斜面を降下していく際に，その運動 が反復継続して持続するかどうかを, 数值解析によりシミュレーションで求めて○×表現の判別表 (表 2) を導出した．同時にその継続性に関寸る成否判別と力積モーメントの大小が関連していることが分かっ た（表 2)．また得られた成否判別が正しいかどうかを確認するために，同条件のもとで実験を行ったと ころ, 同じ結果（表 3）が得られた.

（2）上記（1）より，搬送装置への適用を想定した諸元の異なる楕円体\&角溝に関して，モデル作成に手間 のかかる実験を一々実施して, その転動衝突運動の反復継続性を確かめなくても, 数值解析によりその 成否がわかることになり，転がり搬送装置の最適設計に役立つものと考えている.

（3）楕円体の溝側面との主たる衝突直後に，同じ側面と再度の小さな衝突現象が起きることが数值解析によ り判明したが，実験においても同現象が生じていることが確認された.

（4）目視観察ではあるが, 実験時におけるヨーイング角 $\phi$ の振幅及び周期について解析結果と対比したとこ ろ，両者がほぼ合っていることが確認できた.

ここまでは，回転楕円体形状をした中実物体の転がり衝突を伴う移動式搬送に注目してきた．その他の応用分 野として, 混合すべき複数種の液体等を回転楕円体形状をした容器に封入し, それを反復的に転動衝突させるこ とによって, 搬送作業と同時に攪拌や溶解過程も可能となることより, 飲料水, 酒造や化学工業などへの適用が 期待される.

\section{文献}

藤井文夫, Hsiao, K. M., 小林卓哉, 井上吉弘, 新田高洋, 衝突, 接触, 滑り摩擦および有限回転運動を考慮した 3 D ビリヤード力学，日本機械学会論文集，Vol.82, No.836 (2016), DOI:10.1299/transjsme. 15-00623.

鄭萬溶，鈴木浩平，正弦波励振を受ける剛体ブロック構造物のロッキング振動特性，日本機械学会論文集 C 編， Vol.66, No.645(2000), pp.1453-1461.

栗田裕, 松村雄一, 梅塚紗百理, 中川淳一, 楕円振動を利用した分別搬送（垂直振動が跳躍限界以下の場合), 日 本機械学会論文集 C 編, Vol.74, No.743(2008), pp.1710-1717.

安田裕矢, 渡邊鉄也, 鞆田顕章, 摩擦を考慮したロッキング振動, 日本機械学会論文集, Vol.82, No.838(2016), DOI:10.1299/transjsme. 16-00061.

\section{References}

Fujii, F., Hsiao, K.M., Kobayashi, T., Inoue, Y. and Nitta, T., 3D billiard dynamics with finite rotation, contact, collision and slip friction, Transactions of the JSME (in Japanese), Vol.82, No.836 (2016), DOI:10.1299/transjsme.15-00623.

Jeong, M. and Suzuki, K., A study on rocking vibration of rigid block structure subjected to sinusoidal excitation, Transactions of the Japan Society of Mechanical Engineers, Series C, Vol.66, No.645 (2000), pp.1453-1461 (in Japanese).

Kurita, Y., Matsumura, Y., Umezuka, S. and Nakagawa, J., Separation and transportation of works using elliptical vibration (The case of vertical vibration under the jump limit), Transactions of the Japan Society of Mechanical Engineers, Series C, Vol.74, No.743 (2008), pp.1710- 1717 (in Japanese).

Yasuda, Y., Watanabe, T. and Tomoda, A., Rocking vibration with friction, Transactions of the JSME (in Japanese), Vol.82, No.838 (2016), DOI:10.1299/transjsme.16-00061. 